\title{
KING SAÑJAYA AND HIS SUCCESSORS
}

\author{
W. J. van der Meulen S.J.*
}

In an earlier article ${ }^{1}$ I ventured to identify the Yava country of Sañjaya's charter, with the Jawa-Holing of the Chinese reports, and to locate it in the environs of the Dièng plateau. This charter opens with the preliminary statement that in 732 the king erected his lingga on a mountain known as "the permanent portion," and then proceeds to give praise to Siva, Brahma and Visnu and to depict the marvelous and felicitous country of Yava. Owned by the spirits and intimately connected with a famous Sivaite yoga precinct that was covered with sacred tirtha, Yava was located in the Elephant-Enclosure-Country. All the elements of this description are fully applicable to the Dièng and to no other (less famous) center of the Śiva cult. Moreover, no other such center is known to have its roots in the eighth century. Such an identification is also supported by the mention of the name "Lang-pi-ya" in the Chinese reports (i.e., the Lampyar or Prahu peak), from which the king liked to gaze down over the sea, and in a more general way by the evident location of Jawa-Holing along the north coast of Java. ${ }^{2}$

I further argued that Sañjaya's charter testifies to the evolution of the country into a kind of local super-power during the eighth century, a conclusion which is in accordance with what can be deduced from the Chinese evidence. ${ }^{3}$ The second part of the text makes this even more obvious. In the eighth stanza of this Sanskrit metric inscription we are informed that at that time Yava was ruled

\footnotetext{
* Father van der Meulen, with whose work our readers are familiar from earlier articles appearing in Indonesia, died on January 14, 1979, in Yogyakarta at the age of 69. In his memory we are publishing this article which he was working on at the time of his death, though he had not completed revising it. The article is a continuation of "In Search of 'Ho-Ling,'" which was published in Indonesia, 23 (April 1977), pp. 87-111. Father van der Meulen had lived in Indonesia since 1930. He headed the Department of History at the IKIP Sanata Dharma in Yogyakarta of which he was a "Founding Father." His other writings include: "Suvarnadvîpa and the Chrysê Chersonêsos," Indonesia, 18 (October 1974), pp. 1-40; "Ptolemy's Geography of Mainland Southeast Asia and Borneo," Indonesia, 19 (April 1975), pp. 1-32; "The Purî Pûtikeśvarapâvitâ and the Pura Kâñuruhan," Bijdragen tot de taal-, land-en volkenkunde, 132 (1976), pp. 445-62; "Keradjaan 'Ho-ling,' Tjarita Parahyangan dan Rahyang Sandjaja," Basis, 15 (1965-66).

1. "In Search of 'Ho-Ling,'" Indonesia, 23 (April 1977), pp. 87-111.

2. The tîrtha (places for ritual ablutions) that covered the terrain of Siva, were probably the lakes that are found on the Dièng plateau itself ( $a$ former crater floor) and the surrounding slopes. They are still objects of veneration. In addition to the lake in the center (now a morass), there are those of Terus, Lumut, Warno, Pangilon, Menjer, Cebong, and Merdodo.
}

3. See 0. W. Wolters, Early Indonesian Commerce (Ithaca: Cornell University Press, 1967), pp. 216-18. 
by a king whose name was Sanna. He was the scion of a famous dynasty and renowned for his meritorious deeds. He governed his people with benevolent wisdom and held his enemies in check. His reign, like Manu's, was long and just. But, continues the ninth stanza, after he (Sanna) had ruled for a long time and was finally taken up to the heavenly sphere in order to enjoy a well-deserved rest, his kingdom fell to pieces. Tremendous confusion arose because the people were bereft of their trusted leader.

Fortunately, however, the tenth stanza relates, "someone rose up whose skin had the color of gold refined in the blaze of flaming fire . . . whose arms had the strength of mountain ranges descending from the uppermost peaks, whose head was held high like the summit of the Meru-mountain, whose feet were planted well above the heads of defeated neighbors squatting on the floor around him." $\mathrm{He}$ excelled, moreover, because of his sublime learning and great courage, which enabled him to subject all the surrounding kingdoms. This hero, of course, was none other than his majesty "Raja Srî Sañjaya," the son of Sannaha, Sanna's sister. From the very moment this hero ascended the throne, security and peace descended on the realm and there was no longer any place for the forces of evil. In effect, the charter shows that the initially idyllic condition of Yava was destroyed by violent dissension and a war of succession, but that Sañjaya eventually restored this island of the blessed to its former splendor.

Although Sañjaya is not mentioned by name in the relevant Chinese reports, both the Javanese and Chinese narratives converge on the same eighth century Yava-Jawa as their focus of attention. The Chinese reports, then, confirm that the old kingdom must have entered a new and more powerful era at about the time of Sañjaya. Moreover, it is probably Sañjaya who appears in these reports under the title chi-yen. They contend that the (then reigning) king lived in the Jawakraton, though his ancestor, chi-yen, had (formerly) moved the kraton eastward. Since contacts with China were resumed in 768 , thus most probably after Sañjaya's death, he may have been the said ancestor. It is very improbable that Sanna or one of his predecessors would have moved the kraton because of their obvious association with the old Ho-ling near Dièng. (One of Sañjaya's first successors, however, could have done so.) In any case, if chi-yen (at the time pronounced ki-yan) was meant to represent the Javanese title kryan (mostly written with the honorific prefix ra-as rakryan) as was suggested by $R$. A. Kern ${ }^{4}-$-which seems the most acceptable explanation--the king in question must have made this title a kind of personal epithet so that no one who heard about "the" rakryan could doubt his identity. ${ }^{5}$ There is indeed epigraphical evidence showing that Sañjaya prided

4. R. A. Kern, "Joartan weergevonden?" Bijdragen tot de taal-, land-en volkenkunde (henceforth $B K I), 102$ (1943), p. 546; idem, "Ho-ling," in Orientalia Neerlandica (published under the auspices of The Netherlands' Oriental Society) (Leiden: Sijthoff, 1948), p. 412. Damais considers this derivation "beaucoup plus vraisemblable et phonétiquement defendable" than the derivation from the name Gajayâna (the name of the king of the inscription found at Dinoyo near Malang) proposed by Poerbatjaraka, which seems impossible and is, moreover, indissolubly linked with the equally impossible "flight" theory, the weakness of which will be demonstrated presently. L. Ch. Damais, Review of C. H. Philips, ed., Handbook of Oriental History, in Bulletin de l'École Française d'Extrême-Orient (henceforth $B E F E O), 48$ (1957), p. 654; Poerbatjaraka, Agastya in den Archipel (Leiden: B rill, 1926), p. 109.

5. Raka (raka-i, rake) indicates any member of the nobility, from king to simple squire. It is always connected with a territorial name (raka-i, lord of). Origi- 
himself on this title and that it had precedence over his royal titles even after he became king. The title accentuated the fact that he had acquired the highest power not because of his royal blood but rather through knightly valor. In any case, in an inscription of 907 issued by king Balitung a line of royal successors to Sañjaya is mentioned, a line which Balitung claims as his own. All these kings are first and foremost given the glamorous title "Śrî Mahârâja," after which their respective rakai-titles are mentioned. The founder of the line, however, is the "Rakai Matarâm" with the addition "Sang Ratu Sañjaya." This was obviously a traditional appellation which Balitung did not want or dare to change. ${ }^{6}$ Thus, this ancestor, chi-yen, who moved the kraton, was most likely the rakai (rakryan) Matarâm, whose renown may already at that time have assumed legendary proportions. ${ }^{7}$

It is evident, however, that if this were the case, the contention of Poerbatjaraka, Krom, and others that chi-yen had to flee because of inimical pressures exerted by Srîijaya, and that he buried himself somewhere in East Java, is simply preposterous. The whole setting of both the Javanese and Chinese evidence is one of expansion and increasing power. There is, moreover, no intimation in the Chinese communication that the move was precipitous or forced or that the new kraton-city was in any way inferior in stature to the kraton-city of Jawa. It was probably therefore a strategic move to a more central site, or, perhaps, the planning of a new start, outside the influence of antiquated clan intrigues, for a new line of kings whose ancestral stronghold was less connected with Dièng. It would seem more likely that the (temporary?) return of one (or some) of Sañjaya's de-

nally it must have indicated the lord of the territory referred to, but it seems to have evolved into merely the indication of a certain rank. This process probably started with the more illustrious titles (i Hino, i Halu, etc.), mainly of members of the royal family who were endowed with villages and lands in different parts of the kingdom, but it is uncertain whether control over the territory that led to the creation of the title was still actually implied. Rakryan (or kryan, without the honorific prefix $\mathrm{ra}^{-}$) was an embellishment used by the higher nobility, while rakarayân (raka raya?) was originally reserved for the king. See, for example, J. G. de Casparis, Praśasti Indonesia /l (Bandung: Nix, 1956), p. 254 n. 48; L. Ch. Damais, "Études sino-indonésiennes III : La transcription chinoise Ho-Ling comme désignation de Java," BEFEO, 52 (1964), pp. 131-32; F. H. van Naerssen, "Some Aspects of the Hindu-Javanese Kraton," The Journal of the Oriental Society of Australia, 2, 1 (1963), esp. pp. 17-18.

6. W. F. Stutterheim, "Een belangrijke oorkonde uit de Kedoe," Tijdschrift voor Indische taal-, land-en volkenkunde (henceforth $T B G$ ), $67^{\circ}$ (1927), pp. 172-215 (esp. p. 189).

7. A "King Sañjaya Saga" evidently existed, although the only source still preserved that makes use of this name is an old Sundanese manuscript called Carita Parahyangan, which is probably more or less contemporaneous with the Tantu Panggělaran (referred to in van der Meulen, "In Search of 'Ho-ling, '" p. 96). The life of Sañjaya, who is portrayed there as a Sundanese king-hero from Galuh, is freely romanticized and mythicized. There are, however, a number of remarkably sober passages derived, it seems, from older genealogical material. I will return to these data later. For the Carita Parahyangan, see R. Ng. Poerbatjaraka, "De Batoe-toelis bij Buitenzorg," TBC, 59 (1919-1921), pp. 380-417; J. Noorduyn, "Over het eerste gedeelte van de oud-Soendase Carita Parahyangan," $B K I, 118$ (1962), pp. 374-83, 405-32; idem, "Enige nadere gegevens over tekst en inhoud van de Carita Parahyangan," $B K I, 122$ (1966), pp. 366-74. 


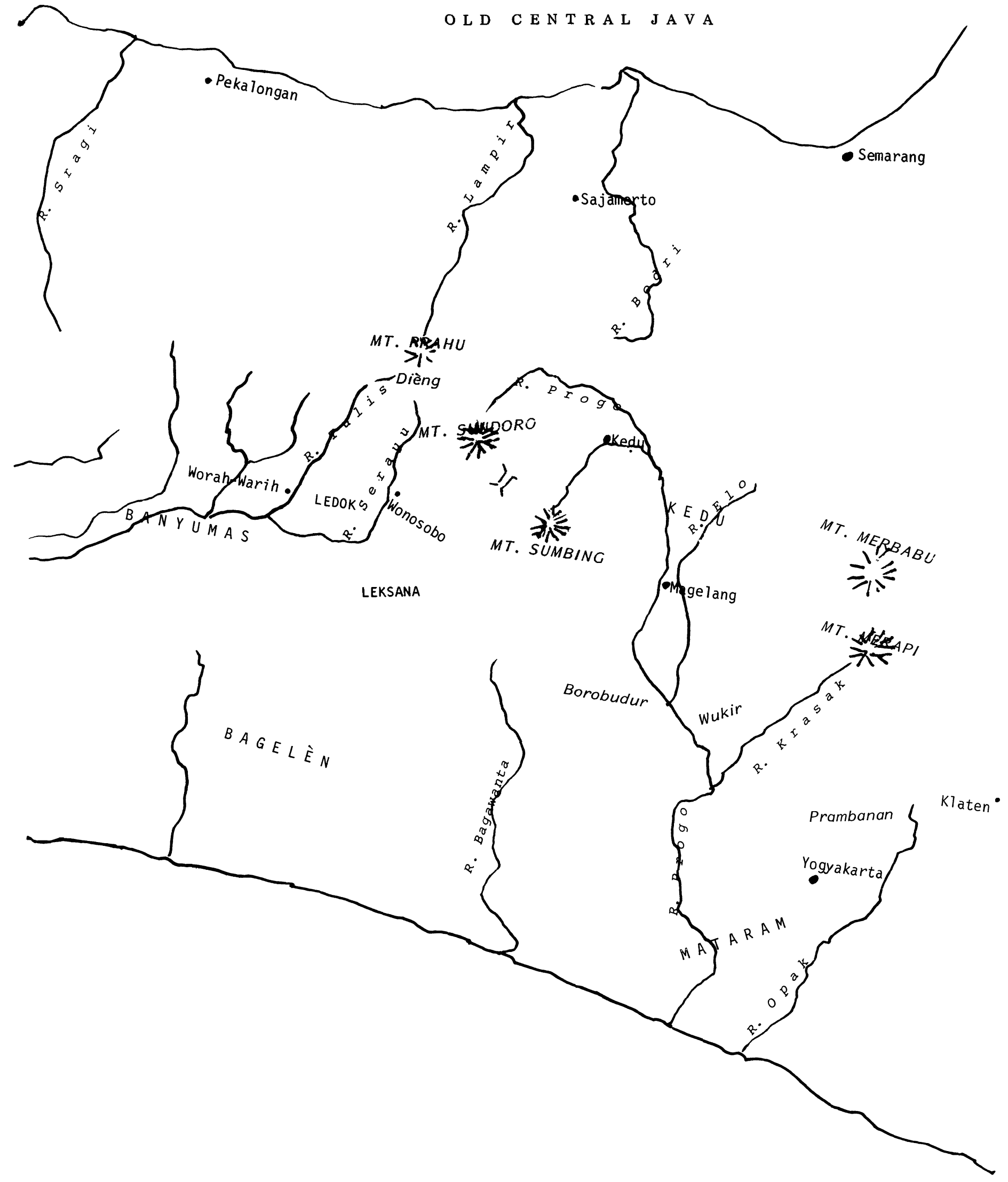


scendants to the old center can be construed as a sign of weakness, but again it may only have been at the instigation of reactionary elements predominating at a certain time.

\section{In Search of the New Kraton-City}

The only indication regarding the location of the new kraton that can be gained from our earlier considerations is that it must have been situated somewhere east of Jawa, i.e., east of Dièng. We can only hope that a more intimate inspection of the few epigraphical monuments (partly from Sañjaya himself, partly from his successors) that point to his presence in the aforesaid region, may offer more specific results.

\section{The Function of the Wukir Inscription}

The only personal communication of king Sañjaya regarding his activities east of Dièng (and as a matter of fact about any of his activities) that has come down to us is the Wukir inscription of 732 , the contents of which 1 related above. If the function of this inscription were known, it might tell us something about the location of the new kraton. There must have been a specific and important reason for a proclamation containing such a solemn summary of royal beliefs and achievements to be placed exactly in this spot. Next to the profession of faith--a kind of spiritual blueprint for the Prambanan temples, where this profession would eventually achieve its expression in stone--the inscription proclaims the king's accession to the throne by the rightful use of force as the son of Sannaha, by which he saved the country from destruction and extended its boundaries. It ceclares his determination to hold his vassals and enemies in firm subjection. Among the approximately 250 Javanese inscriptions known to us, this document is unique. ${ }^{8}$

It is difficult to visualize this inscription simply as a wayside monument, however numerous the multitude of market-going villagers, of peddlers, traders, and soldiers, or even of country gentlemen, that may have passed it every day. Such common people do not count for much in the balance of medieval statecraft. Moreover, they would not have been able to understand the Sanskrit verses. Nor could such an elaborate document have been intended as a boundary stone, especially since nothing is said about boundaries except those that were annihilated by Sañjaya's conquests. Its tone is far from defensive; on the contrary, it proclaims a ruler who feels himself literally on top of the world. ${ }^{9}$ Those "whom it may concern" were not wayfarers or boundary violators, but subjected vassals and defeated kings. In order to be of any use, therefore, the prasiasti would have had

8. The charter shares some common elements with the Śrivijaya documents, but it is among other things much more balanced and devoid of tantric paranoia. The praśasti most similar to it is Erlangga's inscription of 1041, originally from the Pucangan hermitage, now in Calcutta. Erlangga, however, wrote his memoirs, while Sañjaya shows no sign whatsoever of considering his mission accomplished.

9. It is difficult to build an argument on a presumed "strategic position" of the Wukir site, because nothing is known about the political constellation at the time, the location of population centers, lines of communication, etc. The valley of the Progo, of course, marks the natural line of communication between north and south in that part of the island, but to what degree was this important in the eighth century? Several of the names seem to suggest that the southern end consisted primarily of woods, a paradise for hermits and fugitives. This may explain why it became covered with sanctuaries in the following centuries. 
to be placed in a central location where those to whom it was directed had an opportunity of encountering it face to face. No better opportunity, of course, occurred than when they had to pay homage to the king at stated times and were allowed to visit relatives held as hostages in the royal compound.

It seems likely, therefore, that this solemn and beautifully executed document was meant to mark and adorn the center of the empire. The man who issued this proclamation is very expressly "king" Sañjaya. The title "Rakai Matarâm" may have been very dear to him and his followers and have constituted a rallying cry in battle, but here it bespeaks the supreme ruler of a kingdom "girded by the sea and be-breasted with mountains." As ruler, he intends to maintain order and unity in the entire realm. It must be noted that the purpose of this expression of the royal will was not only or even primarily to express his intention, but also to achieve this intention through the magical forces concentrated in the ceremonially consecrated stone. His court Brahmans would have taught him as much. Thus, the praśasti, together with the sanctuary in, or in front of, which it was placed, was a natural part of the kraton and contributed to its accumulation of power. The sanctuary was certainly not situated within the limits of the royal dwelling proper, but it does not seem that these living quarters of the individual king were of first importance or very sacred in themselves. The kraton was the center as a whole, the place where the king lived, which, together with its outlying sanctuaries, formed the ancestral region, the heart of the kingdom, the radiating center that bestowed order and well-being on the realm, whose boundaries were not defined by geographical markings but by the strength and the range of the power that emanated from this center, 10

Such an interpretation becomes more plausible if the lingga mentioned in the first stanza, that is, the sign that marked the establishment of Sañjaya's rule, was erected on the Wukir hill. It is indeed very probable that he placed a lingga on that spot, but I doubt very much whether this was "the" lingga, mentioned in the charter, which was erected on a mountain called "permanent" or "eternal portion." No mountain of that name is known to me, but I still maintain that Dièng was the permanent heritage and cornerstone of Jawa-Holing and its kingship. Sañjaya makes it clear that he did not make use of the confusion rampant after the death of Sanna in order to proclaim himself independent only in a part of the country, by setting up his lingga in some provincial center. In order to establish himself as the rightful successor of Sanna he must have erected his lingga in the ancient center of Yava. Only after this fact was firmly recognized, which may have cost him a considerable number of wars, could he play with the idea of moving his kraton to a more convenient and congenial location. This observation tallies well with a stray notation in a later Chinese source, which places Sañjaya's

10. B. R. $\mathrm{O}^{\prime} \mathrm{G}$. Anderson, "The Idea of Power in Javanese Culture," in Culture and Politics in Indonesia, ed. Claire Holt (Ithaca: Cornell University Press, 1972), pp. 28-29; W. J. van der Meulen, "The Purî Pûtikeśvarapâvitâ and the Pura Kanjuruhan," $B K I, 132$ (1976), pp. 452-53. The title ratu or raja is, for all its archaic simplicity, in no way less comprehensive than the title mahââaja that became the fashion under Sailendra influence and seems sometimes to constitute a kind of compensation for a lack of real power. It is possible that copies on lontar leaf or copper of the formidable mother-charter were distributed. We know that of some inscriptions such copies were made (Stutterheim, "Een belangrijke oorkonde," pp. 172-74). It is also evident that the stonecutter must have worked from a model on palm-leaf or tree-bark. J. G. de Casparis, Indonesian Palaeography (Leiden: B rill, 1975), pp. 5, 7, 28. 
move at between 742 and $755,{ }^{11}$ thus at least ten years after he established himself as the ruler of Yava. But even then he thought it wise to state expressly at the very beginning of his proclamation that he remained the ruler--and the only ruler--of Yava, the true successor of Sanna. In this context it may be noted that the only royal titles mentioned in the inscription are those of Sanna and Sañjaya. The subdued princes are not called kings, they are not given a title at all, they are simply the vanquished ones. The kraton may be moved, but the royal lingga remains immovable on the mountain called "the eternal portion." It is a curious fact, though its importance is difficult to assess, that names like Perboto and Leksono on the southern slope of the Dièng are reminiscent of the parvate ("the" mountain) and lakșana-lakșita (the lingga identifiable by its token) in the same first stanza of the prasasti. ${ }^{12}$

That the inscription does not mention the new kraton is, of course, a serious and disappointing omission from our point of view, although the reasons for it are completely obvious from the standpoint of Sañjaya. Though there are many inscriptions concerned with the sanctuaries of dead kings and especially with the land grants used for their upkeep, there is not a single one that commemorates the foundation of the kraton of a living monarch. Only a few mention in passing the location of such a kraton (a communication mostly of no use to us, because we do not know where to look for it). However great the importance of the kraton as a center of activity, as a building it hardly outlived a single generation, since the materials from which it was constructed could not long withstand tropical conditions. Looking for their remains is for the most part futile; even many later kraton left virtually no traces. Thus, kraton must have been moved and rebuilt quite frequently, though obviously within the limits of a central patrimony, as moving the kraton outside that sphere would be equivalent to founding a new kingdom.

In this particular instance Sañjaya did not have to elaborate the obvious fact that he had moved his kraton. It must already have been resented, and may have brought the kingdom to the verge of rebellion. The move was something unheard of and sacrilegious. For five or more centuries, the center of Yava had been in direct communication with the spirits of the Dièng, and it had never occurred to anyone that it could be transferred outside that sphere. Sañjaya's move challenged the forces of tradition. This sentiment may not have been very pronounced among the common people, but the feeling of outrage was intolerable for many members of the royal family and the nobility who had grown up in the old tradition and remained attached to it, and who had borne the yoke of Sañjaya with difficulty. Even generations later, the restoration of the old order (maybe short-lived)

11. P. Pelliot, "Deux itinéraires de Chine en Inde à la fin du VIIIe siècle," $B E F E O, 4$ (1904), p. 225.

12. The topography of this northern tip of the old province of Bagelèn has other peculiar Sanskrit-derived names, such as Brahol (brahgola, universe), Pasindon (bathing pond; see the segaran in W. F. Stutterheim, De kraton van Majapahit [The Hague: Nijhoff, 1948], p. 16), Sapuran (belonging to the pura), etc. I will discuss the gold and ceramics (mostly ninth century) of the region presently. The name "permanent share" or "permanent portion" may allude to the old adatlaw provision which divides communal land between permanent and changing shares (see esp. "Gegevens over Selokaton," Adatrechtbundels, 25 [The Hague: Nijhoff, 1925], pp. 35-37). The modern names are sawah rojo, pațok, sanggem, etc.

Thus, the lingga would have had the function of the paţok, the mark-post of the owner inscribed with his personal token (lakșana-lakșita). 
aroused such a stir of victorious rejoicing that the Chinese could not help hearing of it. Thus Sañjaya had to muster all the power of his kingship (and probably organize a few expeditions to enforce his royal will), maintaining that his lingga remained immovable at the center, his "permanent share," and that he remained the successor of Sanna, a succession which he had obtained by his valor and would maintain with force if need be. This was his only message; the fact that he had moved his kraton was not in doubt.

It should be clear that these conclusions are based entirely on an analysis of the inscription, which assumes that it is connected with the transfer of the kraton to the east as recorded in the Chinese annals, a move that, according to the same annals, took place at least ten years after the erection of the lingga mentioned in the inscription. It remains to be seen what corroborating evidence can be extracted from inscriptions issued by Sañjaya's successors about the location of this new kraton. ${ }^{13}$

\section{Meḍang, Mamrati, and Matarâm}

Without doubt, the most important of these inscriptions is the Balitung charter. This charter, the main purpose of which will be discussed later, invokes the spirits of those "builders of kraton" who once ruled "in Medang (in) Pohpitu" as supernatural trustees standing guard against violations of its provisions. They are the line of kings, starting with the rakai Mataram, mentioned above. The titles of the successors are: the Mahârâja rakai Panangkaran, Panunggalan, Warak, Garung, Pikatan, Kayuwangi, Watuhumalang and (strangely enough) Watukura, that is, Balitung himself. Two parts of this passage are especially important to us, the title "rakai Matarâm" and the geographical determination "ri Meḍang ri Pohpitu," 14 to which we will first direct our attention.

In several other early inscriptions (eighth-tenth century) Medang is found in combination with two attendant toponyms--Amrati or Mamrati and b̆humi Matarâm-indicating the place of a kadatwan or royal center. ${ }^{15}$ The additional names may be those of domains, districts, or jurisdictions, presumably directly under the king and with one of the highest princes actually in charge. The oldest reference to the name Amrati appears in a copperplate inscription from Pengging (Boyolali), dated 819 , where it is stated that a royal injunction (ajiñâ) of (king) Rakarayân i Garung (the fourth dynast on our list) "descends" on the "sang Pamgat Amrati." The similarity of the formula to those in later inscriptions, where such an injunction is always directed to the mahamantri or mapatih, the highest dignitary after the king (presumably a prince), may indicate that the function of this Pamgat was similar to a minister in charge of royal domains. ${ }^{16}$ In an inscription of 856 , which

13. There is always the rather remote possibility that the stone was moved to this spot from elsewhere, or that several copies of the same stone existed at different locations. This would vitiate our thesis as to the actual location of the kraton, but not necessarily as to the basic purpose of the inscription.

14. Stutterheim favors the translation "in Medang and in Pohpitu" ("Een belangrijke oorkonde," p. 191). In view of the other combinations that will be discussed presently, where the second term is evidently an identifier of Medang, there seems no reason why this "and" should be added.

15. For the use of medang see "In Search of 'Ho-Ling, '" p. 99 n. 45.

16. The text is in Poerbatjaraka, "Transcripties van Koperen Platen," Oudheidkundig Verslag (henceforth OV) (1920), p. 136; R. Goris, "De Oud-Javaansche 
is a hymn in praise of king Jâtiningrat (probably one of the names of rakai Pika$\tan$ ), it is stated that this king (according to the translation of de Casparis) "established his kraton at Madang situated in the country (?) of Mamrati." The same inscription mentions a rakaki (patriarch?) of Mamrati, most probably the king himself. ${ }^{17}$ Another "sang pamgat Mamrati" comes to the fore in a charter from the time of rakai Kayuwangi $(877),{ }^{18}$ while Balitung himself, in a charter of 905 found near Prambanan, speaks of both Medang and Mamrati, but as two separate jurisdictions (watek). ${ }^{19}$ In the inscriptions of Balitung's successors, too, Mamrâti or Mamrati is only used as a function (mamrâti $\mathrm{Pu}$ Dapit) or the name of a district or jurisdiction (Gilikan watek Mamrati). ${ }^{20}$ By that time, however, Medang also begins to appear in combination with "i bhûmi Matarâm."

This later combination "Medang-bhûmi Matarâm," is especially known from the East Javanese inscriptions of the kings Dakșa and Wawa, and from the inscriptions of the East Javanese king Sindok. Balitung was still a Central Javanese king, though he must have had considerable influence in East Java, where at least six of the seventeen inscriptions that bear his name were issued. His immediate successors may be seen as basically still Central Javanese kings, since they continued to invoke the "spirits who protect the kraton of his majesty the king located (in Medang) in the realm of Matarâm," though the stone inscriptions of at least two of the successors point to East Java as the main field of their activities. The fourth successor, Sindok, moved his kraton definitively eastward (but, as with Sañjaya, the new location is not known) and founded a new line of kings. But while sedulously cultivating contacts with the extinct East Javanese dynasties by renovating their shrines, he also invoked the "spirits who protect the kraton of the deceased kings i Meḍang i bhưmi Matarâm." 21

Inscripties uit het Sri-Wedari-Museum te Soerakarta," OV (1928), p. 65. A ramamrâti is also mentioned in the list of functionaries.

17. De Casparis, Prasasti Indonesia /I, pp. 280-330. The same poem says that the king ruled "jawârjawa." As a Javanese-Sanskrit hybrid term, it can be understood to mean "honest Jawa," "true Jawa." It can, however, also be interpreted as a Javanese compound meaning "Jawa possessed by Jawa" and thus as a pun on "Jawâryang" (or "Jawâryèng"), "Jawa possessed by the spirits," which I proposed as the matrix of "Ho-ling."

18. Polengan IV, found near Kalasan. See OV (1938), p. 19. It also mentions "i Mamrati si Śrî."

19. W. F. Stutterheim, "Oorkonde van Balitung uit 905 A.D. (Randoesari I)," in Inscripties van Nederlandsch Indië / (Batavia: De Unie, 1940), pp. 3-28. Both Medalang and Mamrati seem to be mentioned as separate jurisdictional units (watek). There is, moreover, an obscure reference to a "rice-cook emerging in Mamrati," supposedly a certain "sir Samodaya," inhabitant of the village of Singhapura. The man who cooked the sacrificial rice for the ceremonies may well have been someone of high standing.

20. See especially Tlodong's inscription of 919 (K.O.I.), probably from Central Java (N. J. Krom, Hindoe-Javaansche Geschiedenis [The Hague: Nijhoff, 1931], p. 194) and that of Wawa, issued 928 (R. Goris, "Midden-Java: Verslag van den Bouwkundigen Adjunct Inspecteur," OV [1928], p. 86), found in Solo. Both are on copper. For the Tlodong inscription see also Poerbatjaraka, Agastya in den Archipel, p. 77.

21. See J. A. L. Brandes' transcription in N. J. Krom, ed., Oud-Javaansche 
What is most noteworthy about the "Medang ri Pohpitu" of Balitung is that this toponym stands quite alone. It is mentioned nowhere else. This is really not surprising, because it was evidently a creation of the author of the inscription. "Pohpitu," which means "seven mangoes" is simply a pun on amra-ti, a hybrid compound with the same meaning. (It is wisest not to draw any etymological conclusions about the origins of Amrati; these people were interested in sound associations, not in etymology.) Thus, there are only two medang, or, if medang was an individual place name, only one. ${ }^{22}$ Both Amrati and Matarâm are the titles of important dignitaries (the latter even being the title of a king); thus, whatever their later connotations, they must originally have indicated possession of an extensive and important domain. The compound "bhûmi Matarâm," which is comparable to the later "bhûmi Jawa" or "Yawabhûmi," "bhûmi Kaḍiri," "bhûmi Malayu," etc., should probably be considered as the name of the realm, or at least the name of the central counties of the kingdom.

\section{The Merapi Region and the Wukir Site}

But what about their location? If the ancient Javanese ever made maps none has survived. Mataram is a name that came to the fore in later history as denoting both an area and a kingdom. The Islamic Mataram had its center in the Merapi region, originally southwest of the mountain. The districts of Kalasan, Bantul, and Sleman, centered around the modern town of Yogyakarta; the region of the original kraton of later Mataram: Kota Gedé, Kerta and Plèrèd; and the region of the mausoleum of Imogiri--all these are traditionally considered to encompass the region of Mataram proper. ${ }^{23}$ Is this the Matarâm of our inscriptions? The supposition seems reasonable, but this is still a long way from absolute certainty. ${ }^{24}$ We may point out that a good many of the inscriptions mentioned above were found in the environs of Mt. Merapi, but since all of them, with the exception of the Wukir charter, are on copper, they could have been brought from elsewhere. There are, however, two stone inscriptions from the time of Daksa (resp. A.D. 910 and 913),

Oorkonden (henceforth OJO), published as Vol. 60 of Verhandelingen van het Bataviaasch Genootschap (henceforth $V B G$ ) (1913), Nos. 30 (Daksa, 915, Singasari), 31 (Wawa, 924, Ngandat, now in Scotland), 46 (Sindok, 937, Candi Lor), 48 (idem, 943 , Siman). The formula is also found in a copperplate inscription from the collection Dieduksman (Yogya, date unknown), while the inscription from Tloḍong (see note 20) mentions a village (?) Matarâm ing Kamanikan (watek Kahulunàn) next to a watek Matarâm, and that of Wawa a Matarâm watek Karangan. The title Matarâm was still used by Majapahit princes.

22. An inscription of Borotengah, Purworejo (901), mentions an "anak banwa $i$ mdang watek Makudur," where mdang is evidently a name of a village. If our Medang is also the name of a village, the kraton must have been at the same spot for about two centuries, unless it was moved intentionally to a village of the same name, which is highly unlikely.

23. Encyclopaedie van Nederlandsch-Indië (The Hague: Nijhoff-Brill, 1918 etc.), under Mataram (vol. 2, p. 683). The name is also found elsewhere in and outside Java, mostly as the name of a village. It seems to mean a particular kind of flower.

24. Krom, Hindoe-Javaansche geschiedenis, p. 169, thinks that the location of the later Mataram "is not without significance" for locating the older toponym. Stutterheim is of the opinion that the Wukir must have been the center of the older Mataram. "Een belangrijke oorkonde," p. 190. 
one probably and the other certainly from the environs of Prambanan, that try to introduce a "Sañjaya era." ${ }^{25}$ The first one is connected with a shrine at a certain Taji Gunung, founded in commemoration of a former "encampment of king Sañjaya" at this place.

The connection of Sañjaya with Mt. Merapi is affirmed in still another somewhat turbid source, the Carita Parahyangan mentioned earlier, which contends that king Sena (the Sanna of the inscription) had a son, rakai Jambri, who later became king Sañjaya. This, of course, is inaccurate, though Jambri may have been Sañjaya's personal name as a prince. It is said, moreover, that Sanna was defeated by his cousin or stepbrother Purbasora in the seventh year of his reign, whereupon he had to flee and took refuge, together with Jambri, in the Merapi region. After the king died in exile, Jambri decided to recover his heritage. He succeeded in this undertaking after many adventures and after having slain his uncle Purbasora. This story evidently contradicts our epigraphical data. It is possible, however, that the reign of Sanna was not as peaceful as suggested in the inscription, and that its early years were troubled. In order for at least the essentials of Sañjaya's contention to stand, however, Sanna must have regained his throne a considerable time before his death. Sanna's reconquest and Sañjaya's similar conquest later on probably became mixed up in the oral tradition, as frequently happens in that kind of narrative. Despite this confusion, however, it is important that the Carita Parahyangan tells us of a link between Sañjaya and the Merapi region.

It is curious that the inscription mentions Sañjaya's mother, but not his father or the Matarâm title. This is, however, understandable in view of the scope of the praśasti which stresses his relationship to Sanna. Is there a connection between his father and Matarâm? This is certainly possible. The king Sanna could have fled with his family (including his sister, the future mother of Jambri) and have found refuge in the domains of the prince of Matarâm who, after assisting him to regain his throne, received Sanna's sister in marriage. The fact that Matarâm was Sañjaya's family domain and place of origin would explain (and would be the only really cogent reason) why he moved the center from Dièng to Merapi and why Balitung puts the title "prince of Matarâm" before his appellation as king.

Though there are sufficient indications to make a more than casual connection between Sañjaya and the Merapi quite certain and to point to the Merapi as the new center of the kingdom, the exact location of the kraton remains unclear. Only the Wukir inscription seems to give a promising lead. It was located in terrain enclosed by the Batang and Blongkèng rivers, descending from the western slope of the Merapi, and by the Progo, coming from the north, into which the first two rivers empty. The Wukir is the highest of a number of small hills that include the Singobarong, Bedali, and Sari, all of which have the last remnants of despoiled shrines on their summits. Elsewhere, too, we meet evidence of sanctuaries that have disappeared. One of the reportedly richest sites near the Wukir is a village with the very uncommon name Tumbrep or Tombrep, separated by a

25. OJO, Nos. 36 and 35 . They have been in the Jakarta museum since the middle of the nineteenth century; at that time the provenance of stones was not always accurately noted. The district offices that acted as intermediaries in such matters were particularly lax. For the Sañjaya era, see L. Ch. Damais, "Études d'épigraphie indonésienne II (La date des inscriptions en ère de Sañjaya), "BEFEO, 45 (1951), pp. 1-63. 
small rivulet from a village called Medangan. ${ }^{26}$ The district to which this territory belongs is at present called Salam, but in the time of van Aalst (1899) its name was still Remamé (Hoepermans spells it Remamèh). It encompassed the whole territory from the slope of Mt. Merapi to the Progo. ${ }^{27}$ It seems possible that in popular speech Ra-mamrati shed its -rati and became simply Ra-mamya (modern Javanese Remamé), "the" (known) Ramam (estate). ${ }^{28}$ These similarities with the epigraphical data may be useful in the future, but as yet there is still not enough evidence to discount the possibility of coincidence. Their evaluation is in any case difficult.

\section{4. $P^{\prime} o-l u-c h i a-s s u ̈$}

There is still one avenue to be explored, the name of the new kraton-city provided by the Chinese annals, which according to the modern sound value of the characters is written as "P'o-lu-chia-ssü" (French transliteration $P^{\prime} o-l o u-k i a-$ sseu). Starting from the flight-theory mentioned earlier, it was supposed that this name was the transliteration of the Javanese name of some place where chi-yen

26. For a description of the remains found there, see Rapporten van de Oudheidkundige Dienst (henceforth $R O D$ ) , 1914, pp. 261-68; N. W. Hoepermans, "Hindoeoudheden van Java" (report about his expeditions in 1864-67), edited in ROD, 1913, pp. 137-43; J. van Aalst, "Opgaven omtrent verschillende Hindoe-Oudheden voorkomende in de Controle-Afdeeling Probolinggo, Regentschap Magelang, Residentie Kedoe," TBC, 41 (1899), pp. 391-415; OV (1937), pp. 11-12; ibid. (1938), pp. 10-11, 18; ibid. (1939), pp. 14, 21. Though dwarfed between Prambanan and Borobudur, the shrines must have been impressive, a sign that the region was held in reverence even after Sañjaya.

27. Van Aalst, "Opgaven," pp. 391-92. The Muntilan district, then called Probolinggo, included the slopes of Mt. Merbabu up to the Progo. Remamé is still the name of a village ( $d u k u h$ ) near the Chinese hillside tombs visible from the main road. Hoepermans mentions "Ranja Piton" as a village near the Wukir. There are really two adjacent villages, Ngrancah and Piton. Thus the "Pohpitu" pun might not have been entirely original. In his review of de Casparis' Praśasti II, in $B K I, 114(1958)$, p. 319, F. D. K. Bosch calls the Wukir site a "tribal sanctuary" (stamheiligdom) of the Sañjaya dynasty. Neither the expression (perhaps he means "foundation [family] shrine") nor its implication is very clear.

28. Th. Pigeaud conjectures a connection between Mamrati and the modern Javanese mirantèni, "take care of." Th. G. Th. Pigeaud, Java in the Fourteenth Century, 5 vols. (The Hague: Nijhoff, 1963), 5, p. 398. Further reminders of Sañjaya are the copperplate inscription of Jragung (about twenty kilometers southeast of Semarang) and the Senjoyo river on the northeast side of Mt. Merbabu between Salatiga and Tengaran. The first, dated 1100 and rather damaged, mentions a "hereditary property of the descendants of Rahyangta Sañjaya" and a shrine ("sang hyang prâsâda") where sacrifices had to be offered to some beneficiary (whose name is unreadable). See OJO, No. 65; and W. F. Stutterheim, "Oudheidkundige Aanteekeningen," $B K I, 90$ (1933), pp. 282-87. Its connection with Sañjaya himself is not very clear. Moreover, Stutterheim's conviction that it was found at its place of origin is subject to doubt. Near the source of the (at least now) insignificant Senjoyo river were found some interesting remains of a shrine and a stone with writing (sic). Whether the river name or the finds have any connection with Sañjaya is not clear. See OV (1937), p. 18; ibid. (1938), p. 20; ibid. (1940), p. 16. 
took refuge. Thus, Ferrand suggested Waru-Gresik, a combination of the names of two neighboring places never mentioned in the inscriptions, which refer only to Waru or Waharu. Here, according to the completion of the picture by Kern, chi-yen lived and died disguised as a simple nobleman. ${ }^{29}$ If so, it is curious indeed that his hiding place was known as far away as China. Starting as we did, however, from the proposition that chi-yen built a new kraton-city for purposes of his own, the question of the name assumes other dimensions.

The building activity would have been accompanied by the observation of all proprieties. For one thing, the "official" name of the kraton would have been Sanskrit. Chi-yen could not be second to Srivijaya and all the other famous kings of his time and be content with the simple Javanese name of the place where his kraton was located. ${ }^{30}$ Since the Chinese name has evidently no connection with any of the indigenous names in the inscriptions, it must have been this Sanskrit name that was reported in the letter presented by the envoys to the emperor and transliterated by the Chinese. This fact makes a reconstruction easier, because the rules of transliteration of Sanskrit names allowed for little improvisation, and especially because a made-to-order name has to consist of meaningful words, chosen exactly because of this meaning. The last two characters, in view of their $T^{\prime}$ ang sound, can only be reconstructed as "kâŝî" or "kâśi," the only two meaningful words available that conform to the required sound. Kâsî is the old name of the city of Vârânasî or Benares, ${ }^{31}$ while kâsi means fist. Since it was common for the names of ancient Indian cities to experience a rebirth in "Farther India" and since the word "fist" (though excellent as a pun) could hardly be a part of the ceremonial name of a kraton, the only choice left has to be the most holy city of Siva on the Ganges river.

The first two characters seem more difficult to locate. "P'o" ("b'ua" according to ancient pronunciation) can be used for $b h a, b a, v a$, or pha (and maybe $p a$ ), while "lu" gives us a choice of $l u$ or $r u$. But here, too, the meaningful Sanskrit possibilities are very limited. Bharu, an epithet of both Vișnu and Şiva might qualify, but as far as I know it does not appear in Javanese literature. Thus there remains only $B$ hâru, which is part of the name of another famous city of ancient India, Bhârukaccha (the [mangrove?] marshes of Bhâru), at that time a center of international trade, known to the Greeks as Barygaza. ${ }^{32}$ I prefer this

29. Kern, "Joartan," p. 546.

30. Though both the names and the locations of many kraton remain unknown, it may be supposed that every hinduized kraton (such as that of Sañjaya; witness his Sanskrit inscription) had a ceremonial name, both during and after the time of Sañjaya. Besides Śrîvijaya, there were Vyadhapura, Aninditapura, Sambhupura, Mahendraparvata, Hariharalaya, Dvaravati, Ayudhya, Lankasukha, Vijayapura, Wilwatikta (and variants), Surâvâśa (Suroaso), Suravisesa, and, afterwards, Kartasura, Surakarta, Ayudhyakarta, etc.

31. For Kâŝî see, e.g., Alain Daniêlou, Hindu Polytheism (New York: Pantheon Books, 1964), pp. 220-21; R. Grousset, Sur les traces du Bouddha (Paris: Plon, 1929), p. 142. The latter author describes the visit of the Chinese pilgrim Hsuan Tsang to Benares, which at the time [629-645] was already called Vârânasî (Po-lona-sseu).

32. It is not likely that Sañjaya's brahmanic advisers knew the Milinda-pañha, which enumerates "the people of Ujjeni, of Bhârukaccha, of Banâres, of Kosala ..." (The Questions of King Milinda, trans. T. W. Rhys Davids [Oxford: Clarendon Press, 1890-94], 2, p. 211). It seems likely, however, that Bhârukaccha was intentionally changed to Bhârukâŝî. 
name, not only because it is the name of a city, but because, in contrast with Bharu, it is definitely known from Javanese sources. In an inscription of 901 , from the time of Balitung, we read about a certain "rake Śrî̀ Bhâru dyah Dhetâ," in which the appellations $S r\left\{\right.$ and dyah both point to royal affiliation. ${ }^{33}$ "This surmise is indeed substantiated, because the lady in question proves to be the daughter of Pu Bwalu Sanggrâmadhurandara, who bore the title "rakriyân ri Watutihang" in the first years of Balitung's reign, and who was therefore certainly one of the highest princes, probably the king's uncle. The charter in question seems a kind of testamentary disposal wherein a number of sacred places and their estates (with the attached obligations) are bequeathed to his (only?) daughter. It appears as if the Bhâru-title was one of the assets of these descendants of Sañjaya.

The ceremonial name of Sañjaya's kraton was, then, very likely "( $\hat{\mathbf{S}}$ rî̀) Bhârukâŝî." ${ }^{34}$ If the rebirth of an ancient Indian city was a common occurrence, the fact that two of these cities were required to become god-father (or mother) to Sañjaya's kraton was certainly very uncommon and a proof of no small self-esteem. But even if this name may be acceptable as the only possible reconstruction of the Chinese toponym, we are not much nearer to proving that the kraton was located in the Wukir region, except for the evidence provided by Sañjaya's prasasti itself. Such proof may be impossible unless new sources come to light. Nevertheless I note a curious coincidence. In his article "Note on Cultural Relations between South India and Java" Stutterheim promoted the idea that, as a result of a strong surge of Indian influence in the eighth century, the Javanese came to portray their country as a replica of the Ganges valley; the Progo replicated the Ganges itself, and the Elo river the Yamunâ. At the confluence of these two Indian rivers was situated the city, country, and most holy tîrtha of Prayâga (now Allahabad). Therefore, Stutterheim argues, at the confluence of their counterparts in Java is found the village of $\operatorname{Pra}(\mathrm{ya})$ gawati. The Dièng mountain range functioned in the same way as the Himalaya, the Menorèh as the Vindhya, Yogya as Ayodhya. The stupa of Bharhut was matched by the Borobudur. These are some of the keypoints of the plan. ${ }^{35}$ His conclusion is that, if the most holy and excellent city of Siva Kâsî had been given a place, it could only have been in the Wukir region. I believe that Stutterheim's intuition was right.

\section{The Return to the Jawa Center}

It has been noted above how the revised $T^{\prime}$ ang Annals relate that the king lived in Jawa-city, though his ancestor "chi-yen" had moved the kraton eastward to P'o-lu-chia-ssu. It was further observed that this communication must have been the result of reports received from the missions going to China in the periods 768-70 and 813-39. Starting with that of 820, these missions are once more described as coming from "Shê-p'o," while the name "Ho-ling" disappears entirely

33. OJO, No. 23, probably from the environs of Prambanan. Stutterheim, Inscripties, p. $14 \mathrm{n} .2$.

34. Valuka-asi, "sand-sword," is phonetically possible, but does not make sense. Bharu-kâsi $i$, "the fist of Bharu," would not be a very dignified name for a kraton.

35. W. F. Stutterheim, "Note on Cultural Relations between South India and Java," TBG, 79 (1939), pp. 80-82. Idem, "De stichter der Prambanan-tempels," Djåwå , 20 (1940), pp. 218-33. It seems more acceptable, however, that Sañjaya had already conceived the idea of Prambanan (though on a modest scale) which was then carried out by his successors, notably rakai Pikatan (de Casparis, Prasasti II, pp. 305-11) and Balitung. 
from the annals. ${ }^{36}$ In this section we intend to search for the answer to two questions: Can we more or less narrow down the location of Jawa-city? And is there evidence to show when this return to Jawa-city might have taken place?

\section{The Central Counties of Jawa}

Despite our conviction that Jawa-Holing was intimately connected with the Dièng mountain, we may safely agree with the general belief that no royal center could have been located on the plateau itself. However attractive a sojourn there evidently was for ascetics and pilgrims, no one who climbed the mountain (without using the modern motor road) could retain the illusion of encountering at the top the delights of courtly life. The kraton would have had to be in a more accessible and fertile place somewhere near the foot of the mountain proper. One of the more likely locations is the coastal plan at the foot of Mt. Prahu, the "Jabarang$\mathrm{kah}$ ("outside the wall") appearing in the reports of the Java War of 1825. Another possibility is the mountainous country of Karangkobar and Worah-warih, west of Dièng. ${ }^{37}$ Still more probable means the beautiful district once called Ledok and today Wonosobo, south of Dièng, between the upper courses of the Tulis and Serayu rivers, the apex of the big triangle of the (former) Bagelèn province whose southern boundary was the Indian Ocean. ${ }^{38}$ Being on higher ground, Ledok also occupied a strategic position for supervising and giving access to both Bagelèn and (along the picturesque Serayu valley) the lake basin of Banyumas. Finally, to the east of the Prahu-Dièng massif, lies the fertile valley of Temanggung (North Kedu), enclosed between the Sundoro and Sumbing mountains to the south and the mountainous ridge that connects the Prahu and Ungaran mountains in the north. This valley extends to Mt. Prahu and connects with the Wonosobo region, through the Klédung pass between Sundoro and Sumbing or over the ridge between Prahu and Sundoro, and with the coastal plain by a road that runs through Candiroto. To the east it opens into the plain of Kedu in the same manner as the Ledok region into that of Bagelèn.

These four regions (Jabarangkah, Karangkobar and Worah-warih, Ledok, and Temanggung), we may note, were the ones that, though belonging to the "outer territories" (monconegoro and pasisir lands), occupied a special position in the estimation of Islamic Mataram's rulers. The first two territories constituted a traditional appanage for royal kinsmen, and there is evidence to suggest that one of the principal causes of the outbreak of the Java War was the Dutch attempt to bring these lands under direct rule. ${ }^{39}$ Mataram's attachment to them was in any case based on traditional (non-Islamic) grounds, and may have encompassed the still sacral character of Dièng. But the surrounding territories were not sacred to the same degree. Respect for Jabarangkah and Karangkobar could have derived from the tradition of the kingdom of Worah-warih (which may also have

36. Van der Meulen, "In Search of 'Ho-Ling,'" p. 92.

37. For the location of this Worah-warih, which may very well have been Erlangga's adversary in 1031, see the map of Dièng appended to $P$. J. F. Louw, De Java-Oorlog van 1825-1830, 6 vols. (The Hague: Nijhoff, 1894-97); also J. Brandes, "Register op de Proza-omzetting van de Babad Tanah Jawi," VBC, 51, 4 (1900), p. 181.

38. H. M. J. Kollmann, "Bagelèn onder het bestuur van Soerakarta en Djokjakarta," TBC, 14 (1864), pp. 352-68.

39. B. Schrieke, Indonesian Sociological Studies, 2, "Ruler and Realm in Early Java" (The Hague: van Hoeve, 1957), pp. 212-15. 
included the other territories), as Schrieke supposed. But the tradition more likely originated still earlier. There is no evidence that Mataram knew anything about the origin of this tradition (or about the existence of the Worah-warih kingdom). But the more obscure the origin and purpose of hereditary customs, the more the customs themselves become sacrosanct. I would like to suggest that the "special position" of these territories derive, not from a particular kingdom destroyed in 1031, but from the roots of Javanese state-building in Jawa-Holing.

\section{The North, West and South Country in Archaeological Perspective}

Archaeologically speaking, the coastal region is not the least interesting but is the least known. Recently, however, an important stone inscription has come to light, namely, the Old Malay inscription from Sojomerto. Boechari, who published the inscription, supposes it to originate from the earlier part of the seventh century, which makes it contemporaneous with the appearance of the name Ho-ling in the Chinese reports. ${ }^{40}$ After a few badly damaged initial lines (which nonetheless seem to contain some important information) the text begins with an invocation to Śiva, bhațâra Parameśvara, and all the gods; then a "dapûnta Selendra" is mentioned in company with his father, Santanû, his mother, Bhadravati, and his wife, Sampula. The occasion of the inscription may have been the foundation of a family shrine at "lempewângih" (Limpungwangi?). One interesting point, of course, is the appearance of the name "Selendra" used as a personal name at such an early date. Whether a connection exists between this Sivaitic dapunta (religious leader) and the Buddhist dynasty that mysteriously came to the fore about one and a half centuries later (if Boechari's time schedule is correct) is very much an open question. ${ }^{41}$

The other point is the "Malayism" of the text. The language indicates that there were "coastal Malays" on the Javanese littoral very early on--most probably peaceful settlers who gradually blended with the Javanese, since conquest of territories here would be less easy than elsewhere. ${ }^{42}$ They must have engaged in diverse occupations, not only as traders and artisans, but also as literati and religious leaders. ${ }^{43}$ Perhaps bands of them were employed as mercenaries, as is suggested by de Casparis, in which case their leaders could of course achieve considerable influence. ${ }^{44}$ It seems natural, too, that court upheavals and the

40. Boechari, "Preliminary Report on the Discovery of an Old-Malay Inscription at Sodjomerto," Madjalah Ilmu-ilmu Sastra Indonesia, 3, 2-3 (1966), pp. 241-51.

41. Dapûnta is not a royal title, but has religious connotations. This did not prevent its bearer from being a politically influential person or the leader of a religious movement--an, shall we say, archaic Imam Bonjol, Sunan Gunung Jati, or Sunan Giri? Such dapûnta would, moreover, be apt to marry into noble or even royal families.

42. This seems indicated, for example, by the story of queen Si-mo and the "Tazis" from the T'ang Annals (van der Meulen, "In Search of 'Ho-Ling, '" p. 90). The coasts of Borneo in particular were settled by Malay immigrants.

43. These immigrants seem to have founded a sanctuary even on the Dièng itself, as is evidenced by an undated Malay temple inventory (OJO, No. 96). It can only be conjectured whether the village of Malayu on the Dièng (Mangulihi B; Inscription No. 31 in L. Ch. Damais, "Liste des principales inscriptions," BEFEO, 46 [1952], p. 36) was founded by Malay people.

44. De Casparis, Praśasti II, pp. 210-11, 264. 
unrest caused by the exploits of Srivijaya (whose fierce charters point to a high degree of tension) led many tilaka (jewels) of ancient dynasties or many defeated kings to flee and wait (and work) impatiently for a turn of the political tide. Where would they be safer than under the protection of Srivijaya's strongest rival? In addition, however, nothing would have prevented them from occasionally becoming a nuisance to their host. It may further be suggested that, if there is any substance to the list of Sañjaya's expeditions in and outside Java mentioned in the Carita Parahyangan, he certainly would have taken, in addition to the inevitable booty, a number of princely hostages back with him to Java. ${ }^{45}$

The territory southwest of Dièng, from Batu to Mt. Sindoro, presents a much richer picture than the coastal area. It has been the location of important finds of gold objects and brass utensils, especially in the environs of Garung (e.g. , Pasindon), Leksono (Gemuruh) and Sapuran (Perboto), and also in the district of Banjarnegara (Sèrèd and the golden "Bhatâra i Diyang" of Batur). ${ }^{46}$ Add to these finds the many sherds of de luxe Chinese and North Indian pottery that have been recovered, and we have indications that the eighth and especially the ninth centuries were times of rising prosperity. ${ }^{47}$ These finds do not consist only of temple treasures; many were evidently personal trinkets. In the inscriptions, payments in gold are also often mentioned. It is remarkable, however, that the epigraphic material, consisting of stone and copper inscriptions, is limited (insofar as it is dated) primarily to the second half of the ninth century. Nothing like the Târumâ inscriptions has been found here, and the plateau itself has yielded only sparse epigraphic remains, a situation all the more curious since this plateau was one of the oldest "workshops" for Javanese stone masons.

This brings us to another remarkable problem. For as far as building in stone is concerned, the country to the south, i.e., Bagelèn and Banyumas, has nothing

45. The Carita Parahyangan claims that Sañjaya first conquered Java, presumable from west to east, vanquishing respectively Mananggul, Kahuripan, Kadul (or Wiru), Balitar (or Jawa), and Bali (nothing is known about any but the last two). Then he went to Melayu, where he subjected Kemir (Khmer?), Keling (whose king is called Si Vijaya), and Barus. Even China (the coast of Annam?) acknowledged his supremacy (Poerbatjaraka, "De Batoe-toelis," pp. 403-5). Except for Java, this activity probably consisted of a number of marauding expeditions executed under the aegis of Ho-ling. That the king himself actually participated is doubtful.

46. ROD , 1914, Nos. 355-84, 1092-188; OV (1924), p. 105 and ibid. (1940), p. 35; K. F. Holle, "Beschreven metalen plaatjes van de desa Pasindoer [sic]," TBC, 25 (1879), pp. 464-71; J. Brandes, "De verzameling gouden godenbeelden gevonden in het gehucht Gemoeroeh," TBC, 47 (1904), pp. 552-77; F. D. K. Bosch, "Gouden vingerringen uit het Hindoe-Javaansche tijdperk," Diåwä, 7 (1927), pp. 305-20. Bosch remarks that these finds presuppose not only the ownership of gold, but also the necessity of burying it, probably in haste under the threat of an invasion or attack, and the lack of any chance to retrieve it afterwards. Schrieke's suggestion that Erlangga's expedition in 1031 against Worah-warih was responsible is a real possibility, especially since Erlangga himself states that he devastated the land and burned all the villages. The inhabitants who managed to evade the slaughter and flee would not dare to return so long as East Javanese were in control of the territory.

47. OV (1939), p. 21; ibid. (1940), p. 35. We must note that the information we possess is based on stray finds made by villagers in the last century. We know nothing about finds made in the eight or nine centuries before that. 


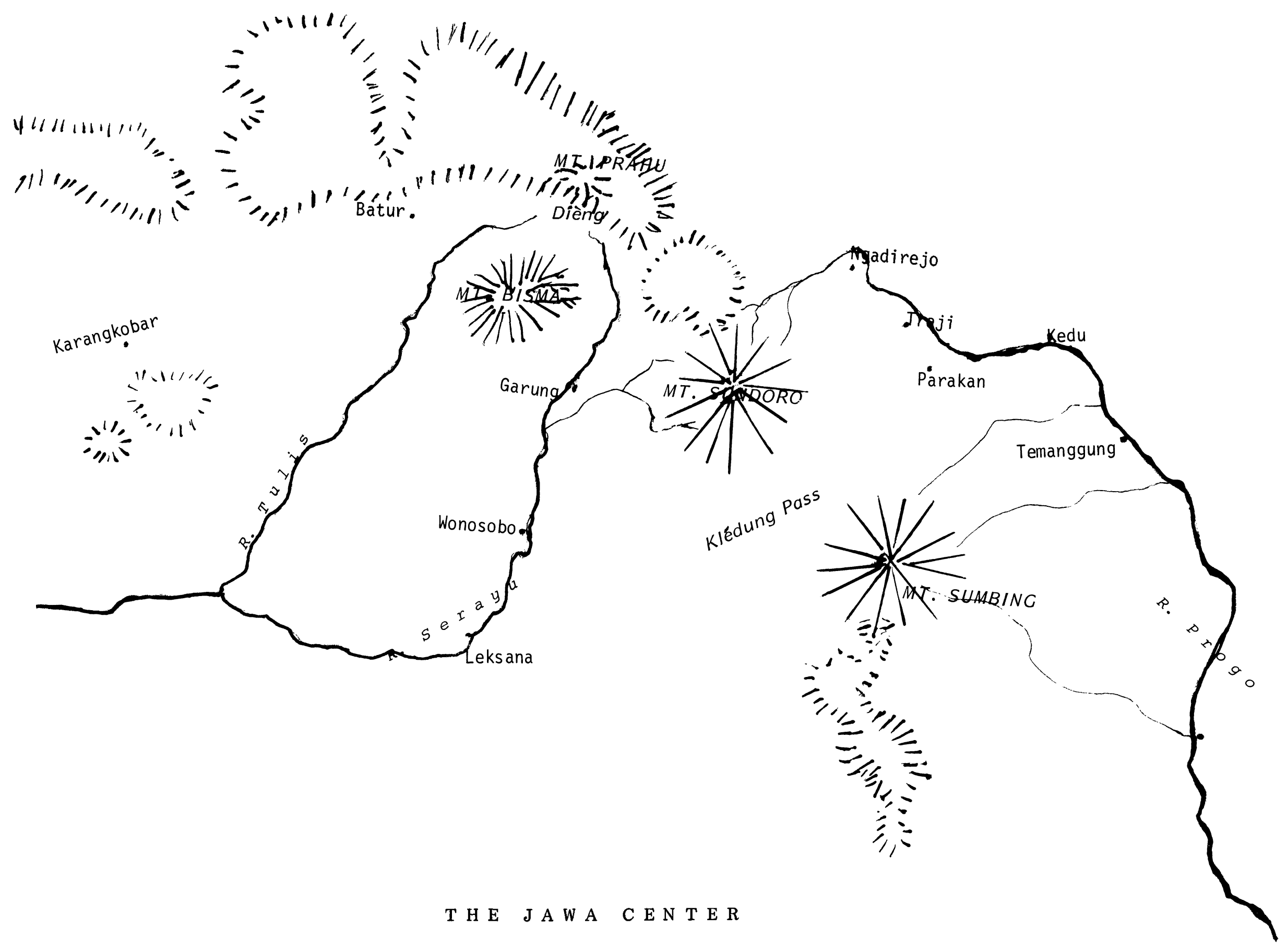


in common with Dièng, indeed seems nearly a-lithic. Even its apex, the Ledok region, is conspicuous in this respect. It is remarkable only for its gold and brass remains--little or nothing in stone survives. If sanctuaries were built, they must have been constructed of wood or perhaps brick, materials that have left scarcely a trace behind. ${ }^{48}$ But for a few cave temples in the southeastern part of the territory, probably the abode of hermits, and a few stray finds, no connection with Dièng can be detected. Even stone inscriptions are only found in the eastern and northern borderland. We must remember that, according to the Wukir inscription, the Yava island of Sanna was conspicuous for its agricultural products, its gold, and its divine spirits. The felt proximity of Dièng as a fortress of Śiva may thus have been fairly recent and a "new" menace to the spirits which had been in possession for so many centuries. (The Saiva (mega)lithic culture of the Dièng area has left traces only to the north, the east, i.e., in the northern littoral, and the plains of Temanggung and southern Kedu, where it came into contact with Śailendra building activity, probably extending up from the south.)

\section{East of Dièng}

The region of Temanggung (North Kedu) lies on the eastern side of the DièngPrahu massif. It is evident from the archaeological remains that it once must have been a country of stone shrines, statuary and lingga. In contrast, gold and bronze are here much less in evidence than in the territories to the south of Dièng. ${ }^{49}$ But conclusions must be drawn cautiously, for it is quite possible that in this district the soil was more intensely cultivated and, therefore, already bereft of its treasures before the Archaeological Service began its work. ${ }^{50}$ Or again, the need to bury such treasures might have occurred less frequently.

The most important part of the region's archaeological inventory, however, is a number of inscriptions dating from the ninth cent ury or shortly thereafter. The original sites where they were found can not always be ascertained, because the records were lost, but they certainly originate from this region, for their contents deal with local land grants. Five of these warrant special attention.

The oldest, the so-called Karangtengah inscription, is dated $824 \mathrm{~A} . \mathrm{D}$. and consists of Sanskrit and Old Javanese portions. The first part is issued in the name of the Lady Prâmodavardhan Samaratunga. In very flowery language it proclaims the foundation of a Buddhist shrine for this glorious and divine late prince by his adoring daughter. ${ }^{51}$ The Old Javanese part, in contrast, is very matter-of-fact. It is issued by (king) Rakarayân Patapân Pu Palar and his queen, who placed the royal revenue of a

48. A few trial excavations made at places where former sanctuaries ought to have been have sometimes brought to light a faint layer of red earth, supposedly all that remains from brick buildings. Stone was less abundant, but not sufficiently scarce to explain this phenomenon.

49. ROD, 1914, pp. 277-305.

50. In the mid-nineteenth century F. Junghuhn (Java, 2 vols. [Amsterdam: van Kampen, 1850], 1, p. 281) was already pointing out the deplorable deforestation of Sumbing and Sundoro occurring as a result of the need to reclaim new land.

51. J. G. de Casparis, Inscripties uit de C.ailendra-tijd (Praśasti Indonesia I) (Bandung: Nix, 1950), pp. 24-49. See also the review article by Bosch in $B K I$, 108 (1952), pp. 193-94. 
number of fields at the disposal of the princess on behalf of her foundation. These irrigated ricefields were located in the jurisdiction of Luapandak and belonged to the villages Kayumwungan, Petir, and Trihaji. That Pu Palar was the king of the realm is evident not only from his title, but also from the fact that he allocated revenues from fields owned not by him but by these villages. From such fields he could only allocate the part due to the king. He would not have used his own domain except on behalf of a family foundation for his own ancestry. ${ }^{52}$

The second text is a rock inscription (thus fortunately immovable) found in Gandasuli near Parakan and dated 832. It is composed in Old Malay and issued in the name of Dang Karayân Patapân Sida Busu Pelâr Ratnamaheśvara, who is undoubtedly the same monarch as $\mathrm{Pu}$ Palar, mentioned above. The text starts with a detailed presentation of the royal family. Following the king and the queen, their relatives are introduced by name--their respective mothers (about the fathers, dead or living, not a word), the younger brother of the king, his two brothers-in-law, his two stepsons or nephews (?), his uncle, etc. The list is completed with the names of their five beautiful daughters: Putih Padi, Tejah Pahit, Swasta, Pagar Wesi and Awak Iṇu ${ }^{53}$

From this detailed introduction we may conclude that the author of the prasasti was evidently very familiar with the royal ménage, perhaps a family retainer in some religious function. Even so, this enumeration would have made little sense unless the readers too were familiar with the inmates of the court. These readers would have been primarily the custodians of the prâsâda (shrine) Sang Hyang Wintang, for whom (and, most probably, by whom) the text was written. This prâsâda seems to have been a family shrine of the Patapân-clan and was probably located in Gandasuli near the rock-inscription. But for the custodians of the shrine to be so familiar with the personalities at the court it could not have been very far distant. It must have been at least in the same region. The language itself does not, as is commonly supposed, prove that the king was of Malay extraction. Whoever it was who wrote the inscription--the custodian of the shrine or someone else--it was in any case not the king. It is doubtful whether the kings of the time had many scholastic abilities. Pu Palar may have known about the existence of the document, but its language originated from a Malay cleric, not from a Malay king.

The third inscription was issued in 842 by a certain "Śrî Kahulunan," a title of the queen, as de Casparis has shown. ${ }^{54}$ De Casparis has also made a strong case for this queen being none other than the Śailendra princess Prâmodavardhanî, who married into the Yava dynasty and became queen after her husband, rakai Pikatan, ascended the throne. Although this inscription may originate from the environs of Magelang, it is evidently concerned with fields in the same territory

52. B. Schrieke, "Iets over het Perdikan-instituut," TBG, 58 (1919), pp. 391428. As far as I know, land or rent grants by a lower-status personage to a higher one do not exist. They would in any case be contrary to the spirit of a feudal hierarchy. Pu Palar bestows a favor on Prâmodavardhanî: anyone could erect a shrine, but only the king could make its upkeep a governmental responsibility. It is therefore unthinkable that $\mathrm{Pu}$ Palar was in any way subject to Sailendra power. The same logic obtains for the position of the rakai Panangkaran in the inscription of Kalasan (779) edited by F. D. K. Bosch, "De inscriptie van Keloerak," TBG, 68 (1928), pp. 58-63.

53. De Casparis, Praśasti I, pp. 50-73.

54. Ibid., pp. 73-95. 
as those appearing in the first two inscriptions.

The fourth inscription is dated 850 , originates from Candi Perot (near Ngadirejo), and was issued during the reign of ratu rakai Pikatan by a rakai Patapân $\mathrm{Pu}$ Manukû. This person must have been very prominent, not only because he obviously endowed the sanctuary from private funds, but also because all the high court dignitaries sent their representatives to the festivities of the consecration. Both the place of origin and the names mentioned in the inscription confirm that it was concerned with the territory we are showing here. ${ }^{55}$

The last of the five inscriptions is the Balitung inscription of 907, with which we are already familiar. According to Stutterheim, it probably originated from Ngadirejo. In any case the lands that are joined into a fund for five patih of Mantyâsih who had given him their moral and active support in connection with his marriage (the passage is not very clear), include waste lands on the slopes "i Susundara" and "i wukir Sumwing" in the district of Patapân. The village of Kdu is also mentioned as collateral (tpi siring) to Mantyâsih. 56

\section{The Restored Yava Kraton}

Though many of the topographical data in these five inscriptions are meaningless to us since they seem to have left no trace in the modern nomenclature of the region, in my view a sufficient number of indications remain to warrant the following conclusions. In the first place, it is evident that these inscriptions are all connected with the same territory. Second, this territory roughly corresponds to the modern district of Temanggung. Third, its center was somewhat further to the north, namely the territory that is enclosed between the upper course of the Progo river originating on $\mathrm{Mt}$. Sundoro and the Kedu river originating on $\mathrm{Mt}$. Sumbing and joining the Progo a short distance east of Temanggung. This triangle (now the district of Parakan, a century ago the district of Kedu) faces the mouth of the Klédung pass leading into the Wonosobo region.

Starting with the places of origin of the inscriptions, we noted earlier that those of Gandasuli (Gs) and Perot ( $\mathrm{Pe}$ ) are certainly both located inside the triangle. Mantyâsih (Mt) probably originated from Ngadirejo (adhirâja, supreme ruler) in the same triangle, while the first inscription is reputed to have been found in Karangtengah ( $\mathrm{Kt}$ ) near Parakan. (According to de Casparis, this report is in error.) All that is known of the Kahulunan (Kh) inscriptions (there are two nearly identical ones) is that they stood in front of the Resident's office in Magelang before being sent to Batavia.

That the contents of these praśasti concern overlapping territories is evident from the number of names of villages and jurisdictions that are common to all or several of them. These jurisdictions were certainly still coherent geographical entities, because the names (with a few exceptions) are only found in this terri-

55. Pu Manukû obviously took over the raka-ship of Pu Palar, although by what process or in what capacity is unclear, no more clear than how rakai Pikatan became king. Thirteen years later, in 863 , what must have been the same Manuk $\mathrm{u} /-0$ issued the charter of Argapura (OJO, No. 8) wherein he calls himself rakai Pikatan. This would have been after the former bearer of the title retired (856) and probably assumed the title of rakai Walaing, and after Kayuwangi became king (de Casparis, Praśasti ll, pp. 249-54). I will return to this topic presently.

56. The term tpi siring indicates a special relation to the beneficiary, something more than just "neighboring" (de Casparis, Praśasti l, pp. 157-60). 
torial context and not in inscriptions originating elsewhere. Several of them function also as village names. Thus we encounter, for example: Patapân (Kt, Gs, $\mathrm{Kh}, \mathrm{Pe}, \mathrm{Mt}$ ), Luapandak ( $\mathrm{Kt}, \mathrm{Kh}, \mathrm{Pe}$ ), Kayumwungan ( $\mathrm{Kt}, \mathrm{Gs}, \mathrm{Kh}, \mathrm{Pe}, \mathrm{Mt}$ ), Petir (Kt, $\mathrm{Kh}, \mathrm{Pe}, \mathrm{Mt}$ ), Trihaji ( $\mathrm{Kt}, \mathrm{Kh}, \mathrm{Pe}$ ), Mantyâsih ( $\mathrm{Kt}, \mathrm{Gs}, \mathrm{Kh}, \mathrm{Pe}, \mathrm{Mt}$ ), Bunut or Wunut (Gs, Kh, Mt), Sukun (Kt, Kh, Mt), Waringin ( $K t, K h, M t$ ), Wuatan (Kt, Kh, Mt), Pandakyan (Kt, Kh, Pe, Mt), Pragâluh (Gs, Kh, Mt), Mundu(an) (Gs, Kh, Mt), Kedu ( $\mathrm{Kh}, \mathrm{Mt}$ ) and some fifteen others that are common respectively to two inscriptions only .

To link up such old names with those on a modern map clearly entails a good many risks. The name Waringin, for example, occurs today as the name of a river and a village. It is a common name and may have no connection whatever with the Waringin of the inscriptions. Other old names may still be extant in corrupt forms and can only be suggested as such very tentatively. I will only point out a few old and new names that are obviously very similar. In the triangle there is a hill called Partapan (971) overlooking the village of Melaran (970), which may have borrowed its name from Pu Palar. Petir and Trihaji (see above) were evidently important and interrelated centers in those times. We still find villages called Petirrejo (i.e., Petir + râja) and Traji $(965,967)$ next to each other along the road from Parakan to Ngadirejo. Kdu, Sumwing, and Susundara are names that speak for themselves. Hajihuma (Mt) may well have been the ancestor of modern $\mathrm{J}(\mathrm{i})$ umo (993) east of Ngadirejo. Kandangan ( $\mathrm{Kt}, \mathrm{Pe}$ ) is of course a common name, but could have something to do with modern Kanḍangan (921) near Kedu. ${ }^{57}$

What is the connection between all this and the Java-kraton or its location? Dr. de Casparis believes that "there is some reason to suppose that there was a dynastic, Caiva, centre in these regions during the Cailendra domination in South Central Java; the Gandasuli inscription might give a hint in this direction." 58 It seems to me that there is much more than a hint about the existence of a royal center here at the end of the period of Śailendra "domination" (whatever this may have been). As is apparent from the contents of the Gandasuli charter, this center must have been in the triangle between the Progo and Kedu rivers, but again it will be difficult to locate the kraton definitively. The most likely place seems to be the village of $\mathrm{Ngadirejo.}$

It may be objected, however, that no rakai Patapân is in evidence as mahârâja in the list of Balitung. De Casparis proposes the theory that the fourth monarch on the list, the rakai Garung, changed his title to Patapân after retiring and devoting himself to religious contemplation. His main argument is that three dynasties existing simultaneously in Central Java (Sañjaya, Patapân and Śailendra) seems too much of an accumulation. ${ }^{9}$ There is, however, I think, no question of a new dynasty, only of a move back to the "old country." Balitung's list is quite in order. He enumerates only those rahyangta who, like himself, resided in Amrati, the eastern kraton. Patapân, too, was a successor of Sañjaya (though

57. The numbers in parentheses are those of the list of archaeological sites in $R O D, 1914$, pp. 261-68. Dr. de Casparis has noted a number of similarities between the names mentioned in the diverse inscriptions and between these names and the names of present-day villages (Praśasti I, pp. 60, 152-55; Praśasti II, p. 231).

58. De Casparis, Praśasti II, p. 229 n. 71.

59. De Casparis, Praśasti I, p. 125. His derivation of Patapân from tapa (Skr. asceticism) seems contrary to the rule that the raka-title is invariably found in combination with an autochthonous toponym. 
perhaps belonging to another line of the family) who set up his kraton elsewhere. This is completely in accord with the Chinese texts. The $T^{\prime}$ ang Annals report the return to Jawa-city. If this report had been the result of the one or two missions of 768-770 (thus not long after the death of Sañjaya) it would have been unlikely to use the designation "ancestor" for chi-yen. It seems, therefore, much more likely that the Chinese received this communication through the missions starting in 813. Moreover, after 820 , the Chinese annals revert to "Shê-p'o" as the common appellation of the kingdom. Both Ho-ling and Shê-p'o had always been connected with the Dièng center. But the Chinese, hearing of a return to Shê-p'o-city, probably began to connect Ho-ling with the eastern capital and changed the name according to the newest reports. This year 820 lies between the time of the last (and only, as far as we know) inscription of the Amrati king rakai Garung (819) and the first inscription of Pu Palar (824), who was evidently not an Amrati king.

This move of the kraton seems not to have outlasted the reign of $\mathrm{Pu}$ Palar. The next monarch we know of is rakai Pikatan, who again is listed as an Amrati king. Was $\mathrm{Pu}$ Palar the first and only king to reside in the Patapân region? I can only offer a theory and some evidence to support it. As mentioned earlier, in view of the way Yava is pictured as a country of agricultural products, gold, and divine spirits, I am inclined to look for the habitat of Sanna in the Wonosobo region. For what it is worth, it may be noted that Sanna is not praised as a Siva devotee, but is said to have "reigned with justice like Manu." In addition to being fundamentally animistic, he may still have followed general brahmanical court rituals, such as are manifest in the inscriptions of Târumâ and Kutai. The Sivaitic infiltration of Dièng, however, would naturally have affected at least part of the royal clan and the nobility. (In the same century, the influence of the Mount Kawi hermits seems to have caused discord in Devasimha's family. ${ }^{60}$ ) The predominantly eastward extension of the lithic Śaiva culture of the Dièng complex indicates that its supporters had or created their center east of the mountain. It must have been this (probably most vigorous) faction that gave its support to Sañjaya, an alliance that would, of course, have been sealed by a marriage. ${ }^{61}$

Thus the country east of Dièng may well have been the place of Sañjaya's first kraton (though possibly not the place where he planted his lingga). The move from there to the Amrati kraton would have been met with resentment. Fundamental ties remained, however, so that it would have been natural, for example, if the Amrati kings sought their principal consort in the old country. This makes the sudden emergence of $\mathrm{Pu} P$ alar as king in these parts more understandable. It seems also to have been the search for a queen that brought Balitung to the north country. The position of the son of haji (petty king) rakai Watuhumalang ${ }^{62}$ obviously needed some strengthening. He not only provided his father with the title mahârâja, but also enhanced his descent from Sañjaya, the rakai Matarâm, with singular emphasis (as did his successor Dakșa and the other kings of the "medang: i bhûmi Matarâm"). It could have been, therefore, that the old country was not very willing to accept him as a son-in-law, so that in some way the patih of Mantyâsih had to support him. Afterwards he gave them lasting authority in the Patapân country, probably to act as his agents, while he enjoined the rahyangta

60. Van der Meulen, "The Purî Pûtikeśvarapâvitâ."

61. The Sundanese Carita Parahyangan notes an alliance with the "tohaan Sunda," whose son-in-law he becomes.

62. This king is mentioned in a copperplate inscription of 896 , where he bears the title haji. 
of Amrati to ensure that his instructions were obeyed. ${ }^{63}$

It is not known whether or how the royal succession was regulated. Patrilinear succession can certainly not be taken for granted. One condition must have been a recognized affiliation to the royal clan, on grounds of descent, marriage, or at least by a kind of transfer or adoption after the fact. In the Chinese accounts we have encountered a queen Si-mo of the seventh century who ascended the throne because "the people of this country [more probably the nobility] took her as their queen." Personal valor and the support of powerful family factions must often have influenced the choice of a successor, and certainly determined his actual power. A strong factor in this connection was a latent matriarchal tendency which manifests itself time and again until the end of the Hindu-Javanese period. We noted how three women hovered over the throne of Pu Palar: his wife, his mother, and his mother-in-law, all three probably belonging to the same maternal clan. His wife actually issued the royal decrees together with her husband. Rakai Garung may have been Palar's father, though more probably he was not. In any case, the author of the inscription thought it unimportant or inopportune to comment on the king's patrilineal descent.

\section{The Successors of Sañjaya}

It will be evident that the Kedu inscription of Balitung (edited in 1927 by Stutterheim), with its list of the successors of Sañjaya who resided in the Amrati kraton, meant an important addition to the very sparse data about this period. Nevertheless, it still leaves even the limited topic of this succession in a state of fragmentation. In this final section I will try to give a short recapitulation of the more solid patches in the obscure historical fabric of this era.

\section{The First Four Amrati Kings}

During the years between roughly 760 and 819 , a period which spanned the reigns of the first four Amrati kings (the raka i Panangkaran, i Panunggalan, $i$ Warak and i Garung), almost no other kings are in evidence. The exceptions are a certain Gajayâna in East Java (760) and a series of Śailendra princes in South Central Java (starting 779). We find Gajayâna living behind Mt. Kawi and, it would seem from his inscription, in very reduced circumstances, bereft of his legitimate patrimony. His difficult situation may have been caused by Sañjaya's onslaught. ${ }^{64}$ The relation of the Amrati kings to the Sailendras is much more important, though hardly clearer. Of the four kings listed above only the last left an inscription (Pengging, Boyolali, 819), the content of which is insignificant except for the mention of a Samgat Amrati. Rakai Panangkaran, however, is mentioned in the first two Śailendra inscriptions, those of Kalasan (779) and Ratu Boko. ${ }^{65}$ It is said there that after the collective guru of the Sailendra king prevailed on the Great-king Tejahpurṇnâpana kariyana Panamkarana (a sanskritization of rakarayân Panangkaran) to grant his permission, they ordered the faithful to start work on a sculpture, shrine, and monastery in honor of the goddess Târâ, under supervision of functionaries of Panangkaran and under the prosperous rule of the royal gem of the Sailendra dynasty. In order to show his respect for the

63. A village name Matesih or Metesih is found in several places, i.a. north of Boja. As noted earlier, Kedu was mentioned as "tpi siring" of Mantyâsih.

64. See above, note 60 .

65. Bosch, "De Inscriptie"; de Casparis, Prasasti /, pp. 11-24. 
guru, His Majesty the Great-king consented to the building of this shrine. He gave the village of Kalasan (as a freehold) to the (Buddhist) community. And he ordered both the Sailendras and their followers, and his own people, to respect and protect the holy place. ${ }^{66}$

With some reservations, I include here as well the name of (what seems to have been) yet another king, the ratu i Halu, who may have been contemporaneous with the first or second Amrati king. ${ }^{67}$ He is mentioned in several inscriptions from the Prambanan region that were issued by his great-grandson (in 856 and 863). This king is said to have arrived from Akhandala-pura (Indrapura), most probably a kraton in Sumatra or the Malay Peninsula, where the name frequently occurs (in Java, "Indra" is practically unknown), and to have settled in Sargabhava (?), (the land) arising from or turning into a stream, ${ }^{68}$ where he founded his "pestle kraton." The phenomenon seems similar to the subsequent Sailendra immigration, though here the prince was a Siva devotee. Damais determines the approximate time of his arrival by taking the term "great-grandson" in its literal sense (not simply in the sense of "descendant"). ${ }^{69}$ His interpretation is probably correct

66. The simple facts that stand out with clarity are that the guru asked and received permission to build a temple and were granted the village of Kalasan as a freehold. This simple message became complicated, however, by a mass of flowery language about an unnamed gem of a mysterious Sailendra dynasty reigning in some unspecified country. This gem may have been connected with the Sailendra who was not able to finish his inscription on the Ligor stone (before 755), probably because he had to flee from the Malay Peninsula in connection with a conflict with Srivijaya. In any case this is the only Sailendra king known to history before the Kalasan inscription. He may have found refuge with the Buddhist community in Java, bringing his royal title, some followers, a resolve to return and not much else. He would of course have been accepted by the Buddhists as their leader, and also have been recognized by the Amrati king as such, the latter being inclined to a laissez aller policy and not sufficiently aware of the eventual political implications. From the Ratu Boko inscription (undated, but epigraphically akin to the Kalasan one) the Śailendra's name emerges as Dharmatungadeva. In the Kelurak inscription, three years later (782), where the Sailendra is called Dharanîndra with the abhiseka (enthronement) name Srî Sangrâmadhanamjaya, the Amrati king is no longer mentioned. It is possible that Panunggalan was not interested or that the Buddhist theocracy felt sufficiently entrenched. We may note, however, that the superlatively bravado language of the guru (several of whom came from Northern India) should not necessarily be taken at face value, i.e., as a proof of strength. It could be evidence precisely of weakness.

67. See van der Meulen, "In Search of 'Ho-Ling,'" pp. 109-10. Stutterheim ("Epigraphica," TBG, 75 [1935], pp. 456-62, esp. 459 n. 1) considers pakwian not as a clerical error for pakwan, but rather as indicating the habitat of his grandmother $(k w i)$. It would have been more logical if the origin of the greatgrandmother had been given also, but Jangluran may have been of higher standing. De Casparis locates this Jangluran in the Purworejo region (Prasasti $I I, p$. 264 n. 92).

68. The reading "Sargabhava" is uncertain. If correct, it may have been an allusion to Bagelèn ( $B$ haga-ili-an, with a weakened second vowel). In this context, if he stayed there as the country's guest, the hypothetical "yavakyapura" would make sense.

69. L. Ch. Damais, "Epigraphische Aantekeningen," TBC, 83 (1949), p. 22. 
because in one of the inscriptions the four generations are expressly given; ${ }^{70}$ the connecting two generations apparently did not have royal status. We will return to this dynastic enigma presently.

\section{The Pu Palar Interregnum}

As we noted earlier, this interregnum seems mainly to have been a period when the maternal clan was dominant. The thesis that $\mathrm{Pu}$ Palar was also a scion of the Sañjaya family is based on the Chinese report that a descendant of this king returned to the Jawa kraton. Both the time when this communication must have reached China and the sudden change of name of the kingdom coincide with the emergence in the Javanese inscriptions of the rakarayân Patapân, a king whom Balitung does not admit to the roster of the kings residing in Amrati. Whether the weakness of $i$ Garung or the imperious disposition of the queen mother Jantakabbi caused the move, is unknown. The safest supposition is that it was the product of a conjunction of several circumstances. As this was the period of the Sailendra decline, their influence can not have been very important, the more so since the cooperation that marked their early relationships evidently re-emerged. Their disappearance, in the same mysterious way as they had appeared about half a century earlier, did not bring with it the disappearance of Buddhist belief or building activity, but these were relegated to a secondary role.

\section{The Raka i Pikatan and Śrî Kumbhaja}

The fifth Amrati king, rakai Pikatan, we have already met as the king of the $\mathrm{Pu}$ Manukû charter of Candi Perot (850). When the same Pu Manuko [Manukû (?)] calls himself rakai Pikatan in 863 (Argapura inscription), the most obvious conclusion is that the former bearer of the title is dead. In any case the king on this inscription, the rakai Kayuwangi, is clearly his successor. A number of the small shrines surrounding the main building of Candi Plaosan Lor (near Prambanan) bear the name of the person for whom they were votive offerings. On four of these is found the inscription "Śrî̀ Kahulunan" (the queen), on fifteen others "Śrî̀ Mahârâja," with or without the addition of "rakai Pikatan." Śr̂̀ Kahulunan is the same queen consort who issued the charter of 842 mentioned above; her husband, rakai Pikatan, must already have been king by that year. Moreover, the lettering of the notices is very similar to that of the charter. ${ }^{72}$

There is still another inscription undoubtedly linked to Pikatan. It is dated 856 and is the oldest example of poetry in Old Javanese (not Sanskrit). It is concerned with the construction of a Siva temple, a Sivagrha, which is pictured in detail and at the least is very probably the beginning of the Loro Jonggrang com pound in Prambanan. ${ }^{72}$ The building of this shrine is attributed to the inspiration of an eminent king named Jâti-ning-rat (Originator of the World, probably a Javanization of Jagatkâraṇa or a similar Sanskrit abhișeka name), who obviously surmounted a severe crisis, but who, after having defeated his adversary, conceived the plan of devoting his life to works of peace and expiation through the building of sanctuaries. He was a Saiva (in contrast to the queen) and renovated his kraton at Medang in the country of Mamrati. As a consequence of his quest for peace, he handed over his kingship and kraton to his successor, dyah

70. De Casparis, Praśasti II, p. 242.

71. De Casparis, Praśasti l, pp. 83-86; 116-17.

72. De Casparis, Praśasti $I I$, pp. 307-11. 
Lokapâla. (which we know to be the personal name of the rakai Kayuwangi). This "handing over" could simply mean that he died, or again it might mean that he retired of his own free will. Under the circumstances, the latter seems more probable. ${ }^{73}$

It seems obvious that Jâti-ning-rat must have been the enthronement name of rakai Pikatan. First, he was an Amrati king (this inscription and that of Balitung are the only ones that explicitly mention the Amrati kraton, as noted earlier) and the father or in any case predecessor of Kayuwangi, whose direct predecessor in the Amrati line, according to the Balitung inscription, was the rakai Pikatan. Moreover, if his Śrî̀ Kahulunan was the Sailendra princess Prâmodavardhanî, which is very probable, ${ }^{74}$ the annotation that he himself was a Saiva while his queen was not is exactly applicable. From his "handing over," it becomes evident that Pikatan reigned (from before 842) until 856.

The word bâlaputra is used in connection with the king's military troubles. It is curious that a king Bâlaputra of Suvarnadvîpa (Sumatra) is mentioned in a charter of the Bengali king Devapâla (about the third quarter of the ninth century), found in the Buddhist monastery of Nâlandâ (North India). This Devapâla writes: "We received a communication through an emissary of the king of Suvarnadvîpa, Bâlaputra, that he had ordered the construction of a monastery [i.e., a residence for student-monks from Sumatra]. Therefore we decided to contribute five villages [as a freehold, free from royal taxes] for its maintenance. . . ." 75 It is further reported that Bâlaputra's grandfather, a "gem" of the Sailendra dynasty, was king in Java (Yavabhûmipâla). His father's name was Samarâgravîra and his mother's Târâ; she was the daughter of (a local Sumatran king) Dharmasetu. It seems therefore more than probable that the "bâlaputra" of our inscription represents a name, the name of the Sumatran king who tried to revive the Sailendra influence in Java built up by his grandfather and to rally the old partisans of the dynasty. His defeat in or shortly before 856 would thus mark the definitive end of this influence. ${ }^{76}$

73. Ibid., pp. 316-17.

74. De Casparis, Praśasti l, p. 131. The fact of this marriage seems to manifest itself also in the abhișeka names of the partners' descendants. See ibid., p. 132.

75. Note the similarity in form with the Kalasan and Karangtengah inscriptions. Nevertheless, nobody will suggest that Devapâla was subjected to Bâlaputra, even if this braggart calls himself "Suvarnadvîpadhipamahârâja."

76. A reconstruction could be suggested along these lines: Prâmodavardhanî was, according to the Karangtengah inscription, the daughter of Samaratunga. Her activity on behalf of her deceased father in concert with the Patapân king becomes understandable if her mother, the first queen of Samaratunga, was a Javanese princess of the Sañjaya clan (not mentioned by Bâlaputra). After the death of this first queen he was contacted by Dharmasetu, the maternal grandfather of Bâlaputra, in search of a suitable consort for his daughter and heir, Târâ, and at the same time of an ally to strengthen his (and her) position. Following this marriage Samaratunga may have changed his name to Samarâgravîra (a common usage). From this marriage Bâlaputra (Junior) was born. Henceforward the king divided his attention between his Javanese and Sumatran interests until, after the death of Dharmasetu, he resided permanently in his Sumatran kingdom. By this time his daughter was also old enough to look after the Sailendra interests in Java, of which she was made his heir (after her betrothal to a 
There are still a few other inscriptions that may have some connection with Pikatan. A number of shorter inscriptions (six to date) have been found on the Ratu Boko plateau near Prambanan; they proclaim the founding of one or several lingga shrines. ${ }^{77}$ Issued by a dignitary who called himself Ŝ́rî Kumbhaja and Kalaśobhava, they are dated in the same year as the inscription of Jâti-ning-rat. This dignitary was mentioned earlier (see above, p. 41) as tracing his descent back to the ratu i Halu, king of the "pestle country." He further calls himself protector and victor of Walaing. The last three inscriptions, of which the texts have not yet been published, contain Śrî Kumbhaja's complete genealogy (starting from the ratu i Halu) ${ }^{78}$ and the information (according to Dr. de Casparis) that he possessed four capitals: "tungam davakyam puram," Langkapura, Nirjjhara, and Valainga.

In addition to these six texts there is also the charter found in Pèrèng near the foot of the Ratu Boko plateau and dated seven years later (863, the same year as the Argapura inscription). ${ }^{79}$ It is issued in the name of a certain rakai Walaing Pu Kumbhayoni, who is a "dhîmân" (an epithet of the famous old sages), and gives a donation to the sanctuary of Bhadrâloka. This man, too, is termed a descendant of the ratu $i$ Halu and is the proud possessor of seven villages whose names are simply the Javanese versions of the so-called kraton above--Tunggang, Dawet (which together constitute "tungam davakyam puram"), Langka, Sèrèh (not mentioned above), Wulakan ni Walâ (Wulakan is "cataract" like the Sanskrit Nirjjhara), Walaing (Valainga) and Lodwâng (not mentioned above).

There seems no doubt whatever that these seven inscriptions were authored by one man: the names are the same (they are all epithets of the famous sage Agastya, therefore the allusion "dhîmân"), the descent is the same, the domains are the same and the Walaing-title is common to both the Ratu Boko and the Pèrèng inscriptions. Who was this person? Was he a king? Was he rakai Pikatan?

Javanese prince?). Note that Bâlaputra proclaims only his grandfather as a king in Java. As crown prince he may already have had an eye on the Javanese inheritance and have established suitable contacts. His opportunity to claim this inheritance and to rally the Javanese supporters of the Sailendra name came after the death of his father and /or of Prâmodavardhanî. After his failure he escaped and simply returned to his Sumatran kingdom. This may have been located in Jambi or Indragiri (with Muara Takus). Srivijaya is in any case not mentioned in the Nâlandâ inscription. That Samaratunga was given his shrine in Java (too) is not an argument against this interpretation. Many kings were deified in different places. How much the picture I have presented here reflects reality can not be easily determined, but it seems the most satisfactory explanation of the facts at our disposal.

77. De Casparis, Praśasti II, pp. 244-79, 341-43.

78. Ibid., p. 342. According to this genealogy, his father commanded the seas like Varuna. This reminds us of the Malay inscription of Dang Pu Hawang (the seafarer) Glis (Gandasuli 1, 827; OJO, No. 3). Note, however, that Pu Hawang is a mythical figure who functions as the patron saint of different people, e.g. , rakai Halaran Pu Hawang (OJO, No. 23 [901]), who is probably identical with the rakai Sirikan Pu Hawang. See Inscription No. 1 (AD 919) in A. B. Cohen Stuart, Kawi Oorkonden [KO] (Leiden: B rill, 1875). Henceforth inscriptions from this volume will be referred to by inscription number, not page. The Pu Hawang Wiwañcana of $O J O$, No. 31 (928), may have been a different person.

79. A. B. Cohen Stuart and J. J. van Limburg Brouwer, "Beschreven Steenen op Java," TBG, 18 (1871), pp. 96-97 and KO 23; Poerbatjaraka, Agastya, p. 48; de Casparis, Prasasti /l, pp. $249 \mathrm{ff}$. It consists of alternating parts in Sanskrit and Old Javanese. 
According to de Casparis, the $\mathrm{Pu} \mathrm{Kumbhayoni}$ of Pèrèng was certainly not $\mathrm{a}$ reigning king, but he may have been a king in retirement. The Śrî Kumbhaja of Ratu Boko uses the royal "Ś̂̂" with this name but not with the other one, Kalasobhava. The text says, however, that he ruled (raraja). The evidence is not very abundant, but there is enough to suggest that he, rightly or wrongly, gave himself some royal prerogatives. De Casparis strongly believes he was once king and was identical with rakai Pikatan. In the metrical Old Javanese inscription of king Jâti-ning-rat, it is said that this king "adopted a name natural to an honorable family of Brahmana," which could of course be intended as an allusion to the adoption of the Agastya name. We are also informed that "after the wicked one(s) ceased to act against him . . . [part of a pada that is unintelligible] this is the reason why this halu here was erected." The exact reason for this erection is not clear from the text. It may have been the king's family origin. The evidence points indeed to Jâti-ning-rat as the author of the other inscriptions, though it is still too vague to be accepted as proof. ${ }^{80}$ There is, however, as far as I can see, no evidence to the contrary, except perhaps the silence about the Amrati kraton (which may be mentioned nonetheless under another name as one of the domains of Śrî Kumbhaja).

It is clear that whoever this person was, he was resolved to play the "Sivaitic Sailendra" and to restore Śivaism to the Prambanan plain, in the first place by rival building activity. ${ }^{81}$ The evocation of the Halu ancestor from Sumatra may have had no other goal than to show off to the Sailendras. Whether the adoption of the Agastya name had the same purpose can be doubted. ${ }^{82}$ I do not see why

80. The curious combination of Siva with Ŝ́ ri-Lakșmi could be an allusion to the name Prâmodavardhanî (charm and increase or prosperity). Vrîdh and its derivations are intimately connected with Srî-Lakșmi. See J. Gonda, Aspects of Early Vișnuism (Utrecht: Oosthoek, 1954), pp. 213, 217.

81. The new Sejarah Nasional Indonesia (ed. Sartono Kartodirdjo, 6 vols. [Jakarta: Percetakan Nasional, 1975], 2, p. 92) propounds multiple conversions, supposing first that Pikatan became a Buddhist and secondly that Kumbhayoni, a scion of the Śailendra dynasty, became a Śaiva and revolted against Pikatan, vanquishing him, together with Kayuwangi (Bâlaputra). Reasons are not given. Perhaps the Buddhism of Pikatan is deduced from the "mahârâja" notices on Candi Plaosan Lor. We must not forget, however, that a king must indulge the devotions of his queen, especially if she happens to have a strong personality and he wants to live in peace. The evidence for Kumbhayoni's being a Sailendra is entirely enigmatic.

82. Agastya was originally a freelance pioneer of Hinduism among the non-Aryan tribes of India, and had no definitive allegiance to one of the chief deities. South Indian popular devotion seems to have brought him into the orbit of Sivaism (K. A. Nilakanta Sastri, "Agastya," TBG, 76 [1935], pp. 480, 539-45). The miscellaneous use of diverse royal names for this sage (Kalaśobhava, Kumbhaja, Kumbhayoni, all meaning "born from a pot or bowl") indicates that these epithets were not official names, but more like nicknames. The mere subjection of the Sailendra foe, however, hardly seems sufficient cause to evoke the feats of Agastya unless there was an important additional reason. The Javanese personal name of this figure, especially if he is to be identified as Pikatan himself, could have provided such a justification. In this connection, we might point to the name of one of the nephews or adoptive sons (the exact meaning of the kinship term is not known) enumerated in the inscription of rakai Patapân of 832, which is Taray ("a basin or tray of copper"; see W. F. Stutterheim, "Oorkonde van Balitung," p. 
any special significance should be attached to the name Walaing. In later times it appears as a simple village and district name, and there seems no reason why it should be taken in another sense here, except for the fact that Ŝ́rî Kumbhaja built his headquarters there and then used it as his rakai seat. ${ }^{83}$ The name does still exist as a village name (whether or not of the same village), though modernized according to exact rules of phonetic change (such as with the village Polèngan [Pawalaingan] near Kalasan.) The name "Walaing" inscribed on a building of the Ratu Boko plateau does not prove that it was the name of that plateau. The sign was not intended to inform tourists about the name of the place, but pilgrims or the deity about the name of the pious donor of the building.

Finally, this person certainly made his mark on the dynastic history of the Amrati and bhûmi Matarâm kings and perhaps even more so on the East Javanese dynasties--or at least his reputed forefather did. To my knowledge, the first person to bear the title "rake Halu" was Pu Catura at the end of the reign of Kayuwangi. Pu Catura had been "rakarayân mahapatih i Weka" for years under the same king. In the reign of Balitung, the rakai i Halu was second in rank, under the mahapatih i Hino. ${ }^{84}$ These facts and the subsequent history of the name prove sufficiently that the ratu i Halu and his great-grandson were no adventurers and no strangers to the Sañjaya dynasty.

\section{Kayuwangi, Gurunwangi and Watuhumalang}

We know the time and manner of the accession to the throne of only one Amrati king--rakai Kayuwangi dyah Lokapâla Ŝr Sâjjanotsawatunga. The element "-(ut)tunga" in his abhiseka name is, according to de Casparis, derived from the Sailendra names indicating his descent from that dynasty by way of Prâmodavar-

22). Supposing that Stutterheim's interpretation of the word taray is correct, it could be objected that its meaning and that of kumbha, pot, are not identical. Nevertheless, in looking for a proper sanskritization of that Javanese name, the use of kumbha could easily come to mind, because its connotations made it honorable enough to be used as an allusion to the king's personal name. This sanskritization certainly fits in with his role as a Śivaite Śailendra.

83. It might be that the esoteric meanings attached to it by Professor Kern, who gave his translation of the passage nearly a century ago, still exercise some influence, or that some connection has been surmised between the Watu Walai, originally a sacred or sacrificial stone, and Walaing. For the appearance of Walaing in the epigraphs, see Damais, "Études sino-indonésiennes III," pp. 121-26. Note also that Walaing never attained any importance in the hierarchical title system, in contrast to the title Halu.

84. For Catura as $\mathrm{i}$ Wka, see, e.g., Ngabean 1 and $4(K O 11,14)$. In $882 \mathrm{Nga-}$ bean $6(K O 15)$, a "bhatâra [lord, deity] i dharmma [votive or sacred foundation] rake Halu i Ramwi ing Pastika" is mentioned next to a "dharmma ing Pastika dharmma rake Halu Pu Catura." The village Ramwi and the dharmma are both said to be located in the watek (jurisdiction) of Halu. This jurisdiction is already mentioned in Ngabean 1 (878), though the beneficiary of the time is not named. The name of a jurisdiction usually originates from the name of a place or region. Here it may have been the other way around, which is equally possible (de Casparis, Praśasti $I I$, p. $254 \mathrm{n} .48)$. For the provision by private persons for the upkeep of sanctuaries, see M. M. Sukarto K. Atmodjo, "The Pillar Inscription of Upit," $B K I, 131$ (1975), p. 252. 
dhanî. ${ }^{85}$. All of his inscriptions originate from Central Java (with the exception of a much later copy that is probably a forgery). The last of the ten inscriptions that mention his name is dated $882,{ }^{86}$ which gives him a reign of at least twentysix years, a fairly long reign at the time. It is a pity that the comparatively large number of charters he issued (it might be more correct to say "in which his name is mentioned") tell us very little about his reign apart from the founding of a number of freeholds for sanctuaries. Nevertheless, the lists of high officials that appear in these inscriptions point to the emergence of a more elaborate organization of the kingdom. There are also indications of some kind of agrarian policy aimed at improving the economic status of the country: dry cultivated areas and woodlands are sometimes donated with the injunction to convert these areas into irrigated fields. ${ }^{87}$ At the end of his reign, however, there are hints that court intrigues were brewing, probably in connection with the succession. We are told that a certain rakryân Landeyan kidnapped his older sister the rakryân Mânak and her child dyah Bhûmi(jaya). The mother died in the process, but the young prince escaped and fled southward to the village of Wuatan Tija, where the people protected him and returned him to his father the king. The king was very pleased, gave them many presents, and made the village into an appanage for his son. 88 Wuatan Tija must have been located in the foothills of the Gunung Kidul due south of Klatèn, where the village Manggung, the site of the inscription, is now situated. We are not informed about the further adventures of Landeyan. Such rebel princes ordinarily stayed in the woods or the mountains, where they could safely maintain their opposition headquarters. Nearly half a century later, there is a memorial to a certain rakryân Landayan ring alas ("in the woods"), erected by his son who had managed to become king.

It is evident that after the death of Kayuwangi the succession was fiercely contested. In an extant inscription of 887 a mahârâja rakai Gurunwangi is mentioned; this is the sole reference to him. ${ }^{89}$ A very dubious charter of 890 promotes a king named Rake Limus dyah Dawéndra. ${ }^{90}$ Only in 896 , with mention of

85. Praśasti I, p. 132. For a list of these abhişeka names, see the register of kings in the Appendix ( $p .53$ ). It might be expected that some vestiges of the Sailendra dynasty survived, apart from the structures they left behind.

86. Ngabean 6 (KO 15).

87. F. H. van Naerssen, "The Çailendra Interregnum," in India Antiqua (Leiden: B rill, 1947), pp. 249-53.

88. W. F. Stutterheim, "Fragment van een inscriptie op brons," $O V$ (1925), pp. 171-73; F. D. K. Bosch, "Transscriptie van een inscriptie uit Goenoeng Kidoel," OV (1926), p. 60; Stutterheim, "Epigraphica," pp. 437-43. Concerning the problem of the date, see ibid., p. 442, and Damais, "Liste des principales inscriptions," p. 40. Note that in the kin term "elder sister" emphasis must be placed on "elder," not on "sister," which covers any kind of female family relation. It is curious (and a bit disquieting with regard to the authenticity of the stone) that we already see here the formula "dewatâ prasiddha mangrakşa kaḍatwan śrî mahârâja i bhûmi i Matarâm."

89. OJO, No. 18. See, however, Sejarah Nasional Indonesia, 2, p. 91.

90. Krom, Geschiedenis, p. 182. This undated inscription on copper issued by a certain "Mahârâja Pu Gwas śrî Jayakîrtiwardhana" originates from North Bagelèn or Banyumas. He probably made himself independent in this region around that time (OJO, No. 104; Krom, Geschiedenis, p. 182). 
"Haji Rakai Watuhumalang," do the epigraphs again correspond with the list of Balitung, whose reign may have been prepared by this haji.

\section{The Rakai Watukura dyah Balitung and His Successors}

The origin of this king is a mystery, especially in that his inscriptions make clear that he reigned in parts of East Java as well. In 905 he even commissioned an expedition to Bali, which was claimed as a success. ${ }^{91}$ Even if this "Bali" referred only to the extreme eastern part of Java, it remains significant. Did this king originate from East Java, or was his influence in that region acquired later as a consequence of a maternal inheritance or a matrimonial dowry? We have already noted that the bulk of his epigraphical work (and thus perhaps of his royal activity) was executed in Central Java. He even seems to have had a different abhișeka name for each of the two parts of his kingdom. In eight of the eleven inscriptions which mention an abhișeka name (several say simply: His Majesty rakai Watukura dyah Balitung) this name is Ŝ́r Dharmodhaya Mahâsambhu. All six of these inscriptions which date from 907 or earlier are found in Central Java. After that time the Mahâsambhu-name is also used in East Java (909, 910). The -tunga name Srî̀ Iśvarakeśavotsavatunga only appears in three inscriptions (898, $902,907)$. The last of these is certainly from East Java (Blitar); the place of origin of the middle one (Watukura) is known; the first is a dubious fifteenthcentury copy found in East Java (Penampihan). ${ }^{92}$ This distribution of the charters seems to point to a progressive unification of the two parts from the kingdom's base in Central Java. The king's last dated inscription was issued in August 910 (East Java) or, if we include the charter of Taji Gunung (reputedly Prambanan) issued by his chancellor Dakșa (then still mahâmantri), in December of the same year.

This rakarayân Mapatị or Mahâmantri i Hino Pu (after 907 Śr̂̂) Daksotama Bâhubajra Pratipakșaksaya is the second mapatih in Balitung's inscriptions. Thus we may conjecture that from 901 he was the king's second-in-command and maybe the man who introduced and upheld his reign in Central Java. ${ }^{93}$ He was a staunch

91. Damais, "Liste des principales inscriptions," p. $46 \mathrm{n} .2$. Bali is here mentioned in its "gentle" or kromo form of Bantan.

92. OJO, No. 21. This inscription is not admitted to the list of Damais ("Liste des principales inscriptions"), who starts the Balitung era with those of Telahap (near the Kledung pass) from 899 and Ayam Teas (Purworejo-Banjarnegara) from 901. Penampihan is certainly not a copy in the strict sense. As in other similar "copies" the original stone must by the copier's time already have reached a certain degree of illegibility so that apart from rendering the inscription in a newer script the "copier" would have filled in obscure parts with the help of traditions, examples from a sort of "Handbook for praśasti composers," or simply according to the principle: my guess is as good as yours. This does not mean, however, that the stone is simply an invention of the "copier."

93. The change to S rî may have meant the elevation to co-regent or designated successor (as also in the case of the mapatih of Tulodong and Wawa). If the story of the subjection of East Java by Sañjaya has any foundation, he must necessarily have followed the usual procedure, i.e., replaced the vanquished kings by scions of his own dynasty or by members of thase old dynasties who allied themselves with the conqueror and married into his family. That no relations over more than a century have so far come to our knowledge does not prove that they did not exist. Thus, for example, a sister of Kayuwangi could have married an East 
admirer of Sañjaya. Both as mapatih and later as king he tried to introduce a Sañjaya era in the Prambanan plain. He was also the man who initiated the formula "dewata prasiddha mangrakṣa kaḍatwan srî mahârâja (i mọ̣ang) i bhûmi Matarâm." He may, therefore, also have been a staunch "unionist" who tried to reunite the old kingdom of Sañjaya. He succeeded Balitung as supreme king, but his reign was quite short. His inscriptions date only from 913 (Gatak, Prambanan) and 915 (Singasari). In an undated charter he is described as concerned with the Bharâha hermitage in the Sâray $\hat{u}$ valley, and he is known to have taken a decision in a dispute around the Dièngese shrine of Haricandana.

In July 919 the first (?) edict of a new king was proclaimed. In it, the mahârâja rakai Layang pu Tuloḍong śrî Sajjanasanmatânuraga-tungadeva ordered endowments to be made for a memorial monument to his father in Turumangamwil. ${ }^{94}$ The name of the father is not given, but the revival of the -tunga element in the king's abhiseka name suggests that he was a son not of Daksa but of Balitung. He had probably not been allowed to play a prominent role either in the reign of his father or in that of Daksa. A few months later (October 919) his mapatih $i$ Hino, Pu Ketudhara (or Ketuwijaya), renewed the decision of Daksa in the Haricandana dispute. The only indication of Tulodong's influence in East Java is his verdict, issued in 921 , in a conflict about the canalization of the river Hariñjing (probably the modern Kali Konto, Paré [Kediri], on whose bank still lies a village called Serinjing). In the inscription the ruler confirms the $\mathbf{7 8 4}$ decision of his predecessor whose funerary memorial is stated to be in Tluk or Twak (thus most probably Panangkaran or Panunggalan).

Tulodong's reign may only have lasted a bit over ten years; for in February 928 we hear of a new king: Śr Mahârâja rakai Sumba (or Pankaya) dyạ Wawa srî Vijayalokanamotunga. He is not altogether a stranger on the scene. An inscription concerning a Śaiva-mandala in Wulakan calls him the son of the Kryân Landeyan sang lumâh ring alas ("whose memorial shrine is in the woods"). 95 If this is the same Landeyan mentioned in the inscription of 882 (see above p. 47), Wawa had had to wait for forty-eight years before he could fulfill his father's (and undoubtedly also his own) ambition to ascend the throne. Forty-eight years seems a long time, especially for that age, but if the kryân Landeyan had been a young man when he committed his crime and had lived a further twenty or twentyfive years, a son, born in exile, ${ }^{96}$ could at the age of forty or forty-five have come to the throne. This would not seem impossible, especially in view of the

Javanese prince. The only hard fact we have is the sudden reunion of Central and East Java under a single king: the question is how to explain this.

94. KO 1; Poerbatjaraka, Agastya, p. 77. Turumangamwil was a village (OJO, No. 103: "anak wanua i turumangamwil") implicated in the Haricandana cult (Wintang Mas) mentioned earlier, and thus to all appearances a Dièng feature. The Layang of the king's rakai title is mentioned in the charter of Taji Gunung ( $) J O$, No. 36), of which the origin is unfortunately not very certain, either as a village or a jurisdiction.

95. This inscription on copper belongs to the Sriwedari museum in Surakarta. It is certainly a Central Javanese inscription. (See Goris, "De Oud-Javaansche Inscripties," pp. 66-70.) Wulakan is mentioned as one of the domains of Kumbhayoni; in 902 it appears to be the name of a district (Kembang Arum, Sleman); here it is the name of a village (district Puluwatu).

96. The word kawawa is listed as meaning "being abducted" by $\mathrm{H}$. H. Juynboll, Oudjavaansch-Nederlandsche Woordenlijst (Leiden: B rill, 1923), i.v. wawa. 
fact that Wawa apparently only reigned for one year. For in April 929 srî Mahârâja rakai Halu (probably a slip of the author of the prasasti for i Hino) Pu Singọ śrî Işânavikrama occupied the throne.

This Pu Sindok had been made a rakai i Halu by Tuloḍong (919), directly below the Mapatih i Hino Pu Ketudhara in the hierarchy. In 926, however, as a Mapatih i Hino with the honorific predicate Śr̂́ he issued the stone inscription of Kembangśsî (modern Bangsri) near Mojosari (Jedung II). Since no king is mentioned in the legible portion of this inscription, we do not know whether Sindok's promotion, presumably on the death of Ketudhara, occurred during Tulodong's reign, or whether Wawa had already become king before 926 . Whatever the case, Wawa's name appears on only three inscriptions, all of which date from 928 . One of these comes from Central and two from East Java (the Minto stone from Ngandat and the stone from Berbek (Kediri) that also mentions a Samgat Landayan Pu Wudya). In the last two Pu Sindok appears as Mapatih $i$ Hino. When he became king, Pu Sindok moved his kraton definitively to East Java, perhaps because he had seen enough of the strife (and violence?) of the Sañjaya family or because he did not want to become the puppet of one of the Sañjaya factions. ${ }^{97}$

\section{An "In Memoriam"}

Starting with the time of Kayuwangi it seems to have become the custom to refer to deceased kings by a kind of posthumous name consisting of an honorific title followed by the name of the place where the king was enshrined. Thus we encounter the "râja sang lûmah [sic] i Layang" (Panunggalan, 896), "haji sang dewata lumâh i Śatașrnga" (Wonogiri, 904), "binihaji sang dewata ing Pastika" (OJO, No. 18 [887]), "sang dewata lumâh (or in pacanḍyan) i Kwak" (OJO,No. 106 [887]), "i caitya ni yayah śrî Mahârâja i Turumangamwil" ( $K O 1$ [ [919]), "sang lumâh i Tluk (or Twak)" (Hariñining, 921), and finally the "kryân Landeyan sang lumâh ring alas," who was at least a pretender. The more general indication for these places is dharmma ("sacred domain") or prâsâda ("shrine," "tower temple"), the more specific caitya or pacandyan, while lumah seems to indicate the act of enshrining itself. It is not certain, therefore, that each dharmma or prâsâda was an ancestor shrine, or that each commemorated bhaţara ("lord") was a deceased king. This problem arises, for example, with regard to the bhațâra of Selingsingan (KO 10), the prâsâda i Candra ( $K O 1_{15}$ ), the dharmma i Wintang Mas ( $\left.K O 20\right)$, and so on.

97. In Hariñjing $C$ (927) a "Pamgat ..... rake Sumba" is mentioned. This indicates that in that year Wawa had not yet become king, so that Sindok clearly must have been Mapatih i Hino during the reign of Tulodong while Wawa was still only (?) a Pamgat (see Damais, "Liste des principales inscriptions," p. $55 \mathrm{n}$. 5). The exact scope of a Pamgat's functions is unknown. A "raka i Sumba" also appears in an undated inscription from about this time found on Mt. Kawi (H. Kern, Verspreide Geschriften, 15 vols. [The Hague: Nijhoff, 1912-28], 7, p. 117). At the end of Tulodong's reign (or between him and Wawa) a certain Mahârâja Pu Wagîswara sang..... (?) (with an unorthodox group of dignitaries) issued charters in 924 (?) and 927 (Stutterheim, "Epigraphica," pp. 430-37). The second was found in the village of Gorang-garèng (Madiun), while the praśasti speaks about a .....(?) ri Garung. For the transfer of the seat of government to East Java and the subsequent darkness falling over Central Java many reasons have been suggested. See especially Schrieke (Indonesian Sociological Studies, 2, pp. 287-301), who advocates a population move and a consequent move of the center of prosperity, trade, and government to East Java. 
These places should not be referred to as "burial sites," ${ }^{98}$ for a dead king (like his subjects) was not buried but cremated, and his ashes were deposited in a river or the sea. Nevertheless, pits have been found in the exact center of many candi where some of the ashes may have been deposited along with votive offerings. ${ }^{99}$ The main purpose of the shrine, however, was not to be a repository for the body but to act as an anchor for the vital power of the deceased to ensure its lasting "political" support. The shrine was thus in a way the late king's permanent kraton (dharmma-pura, KO 15).

Both the location of the sanctuaries and the identity of the king enshrined there are usually uncertain. The location of Selingsingan is supposed to have been northeast of Muntilan (candi Asu-Lumbung), but it is not known whether its bhatâra was a deceased king, and if so which one. ${ }^{100}$ Satasrngina and Turumangamwil are most likely Dièng toponyms, though their exact location can not even be guessed. The king in possession of Satasrnga must have been a predecessor of Balitung (for he is mentioned in one of Balitung's prasasti), and we have argued that the father of Tulodong "candified" at Turumangamwil was probably Balitung himself. ${ }^{101}$ Upit (and probably Kwak, too) was located north of Klatèn, ${ }^{102}$ and if the $\mathrm{Twak}$ of the Hariñjing inscription is a misspelling for $\mathrm{Kwak}$, it must have been the permanent residence of Panangkaran or Panunggalan. The important dewata ing Pastika could have been Kayuwangi (according to Poerbatjaraka) or Pikatan (de Casparis). It is not impossible, though rather unlikely, that a binihaji ("wife") of Pikatan still survived in 887 (the king died around 856 or 863 , as we argued earlier). ${ }^{103}$ On the other hand the bhatâra and dharmma of Pastika were already mentioned in 881 and 882 , when Kayuwangi was evidently still living, and thus not ready for cremation. He may, however, have prepared a place for himself near an already existing sanctuary (whether of one of his forebears or of another good genius). This is the more probable since the "śrî mahârâja sang lumâh ing Pastika" who gave the first decision in the Haricandana dispute and is mentioned in an inscription of 919 ( $K O 20)$, can hardly have been the rakai Pikatan. We hear for the first time about this dispute in 878 (Wintang Mas A) when an agreement was made about the juridical standing of the sanctuary. This agreement not only shows no trace of royal interference, but also does not mention a previous royal decision (which would certainly have been the case if there had been one). Though we do not know the exact date of Pikatan's death,

98. On this subject Dr. Sukmono wrote his (so far unpublished) thesis at the Universitas Indonesia.

99. Practically no pits were ever intact, for golddiggers had always preceded the archaeologists. It is, therefore, difficult to ascertain for sure what the original contents and purpose of these pits were.

100. Selingsingan was mentioned in "In Search of 'Ho-Ling," p. 108.

101. See note 94 . The village seems to have belonged to a Buddhist monastery and to have fallen under the jurisdiction of Kahulunan (Wulakan, 928).

102. Sukarto, "The Pillar Inscription," p. 249.

103. This inscription (OJO, No. 18) states that the binihaji of the king enshrined in Pastika, sang hadyan Palutungan, together with her elder brother, made provisions for the shrine. A binijahi was not necessarily the principal consort of the ruler (P. V. van Stein Callenfels, "Bini-haji," OV [1922], pp. 82-84). So she could have been quite young when the king died. 
we can be quite certain that it had occurred before 878 . It therefore appears that only Kayuwangi could have been the "lumâh ing Pastika." 104

This "in memoriam" is not very enlightening, perhaps, especially for those who are bent on visiting the permanent kraton of the Amrati kings. But even had we been provided with better guidance, a few scattered stones might be all that now remains of these glorified permanent shrines.

104. It is nevertheless curious that pikatan ("trapper," "bird-catcher") should be pâśika in Sanskrit (Skt. pastika means crystal, jewel). 
Appendix

REGISTER OF KINGS 732-928 (tentative)

POHPITU/AMRATI I:

Dates of

Inscriptions :

732

sang ratu Sañjaya

$\pm 760-819$

Rakai PANANGKARAN*... (?)

srî Tejạ̣purṇṇâpaṇa

Rakai PANUNGGALAN *...(?)

Rakai WARAK* ...(?)

Rakai GARUNG*...(?)

YAVA :

Rakai PATAPÂN, Pu Palar, śrî Ratnamaheśvara

POHPITU/AMRATI II :

Rakai PIKATAN, * (dyạ

Kumbha?), śrî Jâti-ning-rat .

Rakai KAYUWANGI, * dyah Lokapâla, śrî Sajjanotsavatunga.

824,832

$842,850,856$, (863?)
$856,860,863$, $873,875,877$, $879,880,881$, 882
Annotations :

Founder of the Amrati line, according to Balitung.

Mentioned in the 779 Sailendra inscriptions of Kalasan and Ratu Boko.

No Amrati king is mentioned in the Sailendra inscription of Kelurak (782).

Hariñjing 784.

Sang lumâh ing Twak (=Kwak?)?

The Pu Palar interregnum began in 820 ?

Married to Śailendra princess Prâmodavardhanî. The Bâlaputra of the Nâlandâ inscription, \pm 860 . Retired in 856 as rakai Walaing Pu Kumbhayoni?

Opposed by kryân Landeyan sang lumâh ring alas.

Sang lumâh ing Pastika?

?? ?

Rakai GURUNWANGI

887

AMRA TI III :

Rakai WATUHUMALANG,*...(?)

896

Rakai WATUKURA, * dyah Balitung, ŝrî̀ Dharmodaya Mahâsam898,899 , 901 [2], bhu (śr̂̂ Iśvarakeśavotsavatunga; 902 [2], later: -keśavasamarotunga) 903,904 , $905[2], 906$, $907[3], 909$, $910[2]$

Central and East Java. Sang lumâh ing Turumangamwil? 
MATARÂM :

Dates of Inscriptions :

Rakai HINO, Pu Dakșotama, śrî Bâhubajra Pratipakșakșaya.

Rakai LAYANG, Pu Tulọ̣ong, śrî Sajjanasanmatânuraga-tuñga .

Rakai SUMBA (Pan̉kaya), dyah Wawa, srî Vijayalokanamotunga
$913[2], 915$

919,921

$928[3]$

* Listed on the Balitung charter of 907 .

Son of kryân Landeyan sang lumâh ring alas. 